\title{
Genomic analyses reveal FoxG as an upstream regulator of wnt1 required for posterior identity specification in planarians
}

E. Pascual-Carreras ${ }^{1}$, M. Marín-Barba ${ }^{3}$, S. Castillo-Lara ${ }^{1}$, P. Coronel-Córdoba ${ }^{1}$, M.S. Magri ${ }^{2}$, G.N. Wheeler $^{3}$ J.F. Abril ${ }^{1}$, J.L. Gomez-Skarmeta ${ }^{2}$, E. Saló ${ }^{1^{*}} \&$ T. Adell ${ }^{1^{*}}$

\footnotetext{
${ }^{1}$ Department of Genetics, Microbiology and Statistics, Universitat de Barcelona (UB) \& Institute of Biomedicine of Universitat de Barcelona (IBUB), Barcelona, Spain.

${ }^{2}$ Centro Andaluz de Biología del Desarollo (CABD), Universidad Pablo de Olavide, Sevilla, Spain.

${ }^{3}$ School of Biological Sciences, University of East Anglia, Norwich Research Park, Norwich, UK.

“Corresponding authors: Emili Saló (esalo@ub.edu) and Teresa Adell (tadellc@ub.edu)
} 


\section{Abstract}

Embryonic specification of the first body axis requires the formation of an Organizer, a group of cells with the ability to instruct fates in the surrounding tissue. The existence of organizing regions in adults, i.e. during regeneration, which also requires patterning of new tissues, remains unstudied. To that aim, we study regeneration in planarians, flatworms that can regenerate any missing structure, even the head, in a few days. In planarians, as described in embryonic models, the cWNT pathway specifies the anterior-posterior axis. During the first 12-24h after amputation both wnt1 and notum (a Wnt inhibitor) are expressed in any wound, but 48 hours later they become restricted to posterior or anterior facing wounds, forming the anterior and the posterior organizers, respectively. In this study we undertook a genomic approach to further understand the mechanism that triggers the early expression of wnt 1 and the specification of the posterior identity. Through ATAC-sequencing and CHIPmentation techniques we uncovered Cis-Regulatory Elements of Schmidtea mediterranea genome and analyzed them in notum and wnt1 (RNAi) animals. The result shows that already at 12 hours after amputation the chromatin structure of the wounds has changed its conformation according to the polarity of the pre-existing tissue. Analysing the DNA binding motives present in the proximal regulatory regions of genes down-regulated after wnt1 (RNAi) we found a few genes containing a TCF binding site, which include posterior Homeobox genes and chromatin remodelling proteins, suggesting that those are direct targets of the cWNT pathway and the responsible to trigger the expression of the posterior effectors. Furthermore, we have identified FoxG as an up-stream regulator of wnt1 transcription, probably though binding to an enhancer found in its first intron. Silencing of foxG inhibits the early phase of wnt 1 expression and phenocopies the wnt1 (RNAi) phenotype, indicating its early role in specifying posterior versus anterior identity. Moreover, we have created a new open platform to interpret all transcriptomic and genomic results obtained (https://compgen.bio.ub.edu/PlanNET/planexp). 


\section{Introduction}

During embryonic development specification of the body axis is one of the earliest events, since it creates a coordinate system to which refer when building all organs and tissues. Specification of the first body axis requires the formation of an Organizing Center or Organizer, which refers to a group of cells with the ability to instruct fates and morphogenesis in surrounding cells, giving rise to specific organs and tissues (1-3). Spemann and Mangold were the first to demonstrate that the dorsal lip of a newt early gastrula had the ability to generate a fully patterned secondary axis when grafted to the opposite site (4-8). The homologous organizer is found during gastrulation of all vertebrates, receiving different names, as the Hensen's node in birds (9), dorsal shield in fish embryos (10) . The difference between Organizers and Organizing centers is commonly attributed to their ability to pattern a whole body axis or just an organ or tissue, respectively. Organizing centers have been identified in several stages of development, for instances in the limb bud of tetrapods or the isthmic organizer at the midbrain-hindbrain boundary $(1,11,12)$. Although organizers are commonly studied in embryos, the very first experiment that demonstrated the existence of an organizer was in fact performed in adult hydras by Ethel Browne in 1909. Ethel Browne transplanted non-pigmented head tissue into the body column of a pigmented hydra and observed the induction of a secondary axis that was composed by the cells of the host (13). More than a century later the existence of organizing regions in adults, i.e. during regeneration, which also requires re-patterning of tissues, is not well studied. To that aim, we study the process of regeneration of planarians, flatworms which can regenerate any missing structure, even the head, in a few days. Thus, they are whole body-regenerating animals, which need re-patterning the body axes to regenerate the proper missing structures according to the pre-existent polarity.

Planarians plasticity is based on the presence of a population of adult pluripotent stem cells (called neoblast) $(14,15)$, together with the continuous activation of the signalling pathways that instruct the fate of these stem cells and their progeny. Several studies demonstrate that 
bioRxiv preprint doi: https:/doi.org/10.1101/2020.12.08.416008; this version posted December 9, 2020. The copyright holder for this preprint (which was not certified by peer review) is the author/funder, who has granted bioRxiv a license to display the preprint in perpetuity. It is made available under aCC-BY-NC-ND 4.0 International license.

the muscle layer that surrounds the planarian body is the source of the so-called Positional Control Genes (PCGs), which are secreted factors that confer axial identity to the rest of the cells (16-19). A subset of these muscular cells located in the most anterior (tip of the head) and the most posterior (tip of the tail) ends of the planarian body act as Organizers. The anterior tip expresses notum (a secreted cWNT pathway inhibitor) and the posterior tip secretes wnt1 (a cWNT pathway activator), and inhibition of those genes produces a shift in the polarity, originating two-tailed or two-headed planarians after silencing notum or wnt1, respectively (20-22). Thus, in planarians, as described in several embryonic models, the cWNT pathway specifies the anterior-posterior axis (23-28). Importantly, during the first 1224 hours of regeneration (hR) both notum and wnt1 are expressed in muscle cells of any wound, and it is not after $36 \mathrm{hR}$ that they are restricted to the tip of the anterior or posterior facing wounds, respectively $(20,22,29)$, forming the anterior and the posterior organizing regions. It is known that the late localized expression of notum and wnt 1 depends on the proliferation of stem cells, and that it requires the expression of some transcription factors, such as foxD, zicA, prep or pbx for anterior tips (30-34) and islet, pitx and teashirt (tsh) for posterior tips (35-38). However, the triggering of the early expression of notum and wnt1, which does not depend on stem cell proliferation, is not understood, as well as the molecular mechanism that restricts each factor to its corresponding pole and the following molecular events that take place to finally regenerate the missing structure.

In this study we undertook a genomic approach to analyse the formation process of the posterior Organizer during planarian regeneration. Through ATAC-sequencing and CHIPmentation techniques we uncovered Cis-Regulatory Elements (CREs) of Schmidtea mediterranea genome (39) and we analysed their accessibility in wild type (wt), notum and wnt1 (RNAi) regenerating wounds. Our results show that already at $12 \mathrm{hR}$, anterior wounds of notum (RNAi) animals resemble wt posterior wounds, and posterior wounds of wnt1 (RNAi) animals resemble wt anterior wounds. Thus, during the first hours after amputation, before the expression of any anterior or posterior marker, the chromatin structure of the 
wounds has already changed its conformation according to the polarity of the pre-existing tissue. Analysing the DNA binding motifs upstream of genes down-regulated after wnt1 (RNAi) we found a few genes containing a TCF binding site, suggesting that those are the genes directly regulated by the cWNT pathway (Wnt1-ß3catenin1) and responsible to trigger the posterior program. Finally, we identified a putative enhancer located in the first intron of wnt1 containing a FoxG binding site. Silencing of foxG inhibits the early and the late phase of wnt1 expression, but not notum, and phenocopies the wnt1 RNAi phenotype. This result suggests that FoxG directly regulates the early expression of wnt 1 in any wound and is a key factor in triggering the formation of the posterior organizing and thus specifying posterior versus anterior identity.

Finally, we have created a new open platform to query and interpret all transcriptomic and genomic results obtained (https://compgen.bio.ub.edu/PlanNET/planexp). An additional web-tool has been developed in order to search for transcription factor binding sites and to $\begin{array}{llll}\text { explore the newly predicted elements } & \text { regulatory }\end{array}$ (https://compgen.bio.ub.edu/PlanNET/tf tools).

\section{Results}

12 hours after amputation the chromatin structure of cells in the wound has changed according to the polarity of the pre-existing tissue.

To identify cis-regulatory elements (CREs) that after amputation could specify anterior or posterior identity, we performed ATAC-sequencing and CHIPmentation of anterior and posterior wounds 12 hours after post-pharyngeal amputation of Schmidtea mediterranea (Figure $1 \mathrm{~A}$ ). At this regeneration time point the early expression of the cWNT elements notum and wnt 1 is first detected, although it is still not polarized $(20,22,29)$. The comparison of the results obtained when analysing anterior versus posterior wounds allowed us to identify ATAC-seq peaks corresponding to accessible chromatin regions (ACRs) specific for 
each pole (DiffBind, FDR $<0.05, \mathrm{fc}>2$ ). We found 611 specific anterior ACRs and 2484 specific ACRs of posterior (Figure 1, Table S1). Comparing those ACRs with ChIPmentation of samples also corresponding to $12 \mathrm{hR}$ anterior and posterior wounds using the H3K27ac antibody, which allows the identification of active enhancers $(40,41)$, we were able to identify a list of 555 anterior putative active enhancers and 1869 posterior putative active enhancers (Figure 1 and Table S1).

Silencing of notum or wnt1 during planarian regeneration produces a shift in polarity, giving rise to anterior tails in notum (RNAi) animals $(20,42)$ and posterior heads after wnt1 (RNAi) $(21,22,43)$. With the aim to analyse the chromatin changes occurred during anterior and posterior specification, we performed ATAC-seq of notum (RNAi) anterior wounds and wnt1 (RNAi) posterior wounds, both at $12 \mathrm{hR}$. We analysed the state of the anterior and posterior putative active enhancers previously found to be specifically open in anterior or in posterior in those RNAi samples. The result shows that in notum (RNAi) anterior wounds only $12.3 \%$ of the anterior putative active enhancers were open, while the rest of them were closed or reduced their accessibility (Figure 1B and Table S1, https://compgen.bio.ub.edu/PlanNET/). Moreover, $87.7 \%$ of the posterior putative active enhancers were now accessible in notum (RNAi) anterior wounds. In wnt1 (RNAi) posterior wounds only $24.5 \%$ of the posterior putative active enhancers were open and the rest were closed or had decreased its accessibility. Furthermore, $31.4 \%$ of the anterior putative active enhancers appeared now open in wnt1 (RNAi) posterior wounds and $9.5 \%$ became more accessible (Figure 1B and Table S1). The finding that in notum and wnt1 (RNAi) wounds the accessibility of the chromatin changes as soon as $12 \mathrm{hR}$ demonstrates that few hours after amputation, much before the first anterior or posterior markers appear (around 48hR) (44), the chromatin structure of the cells in the wound has already changed according to the polarity of the preexisting tissue. 
a
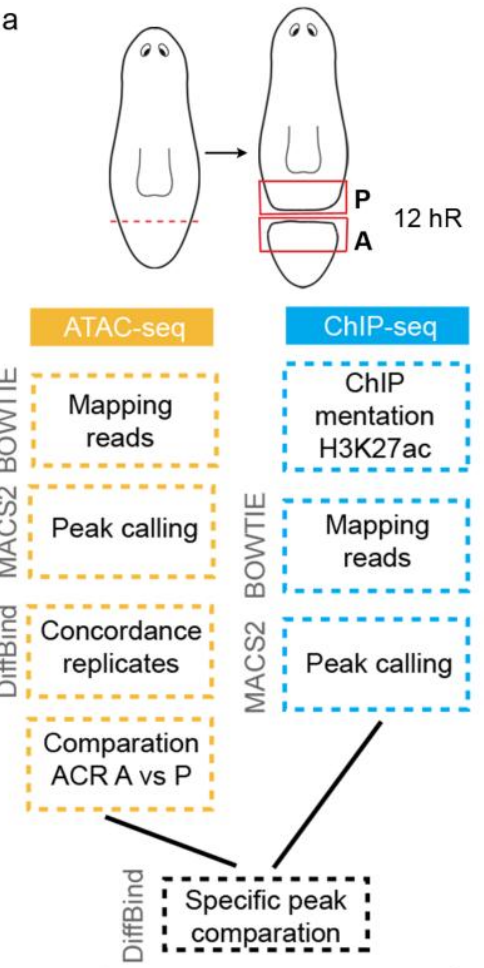

555 A Active enhancers 1869 P Active enhancers b

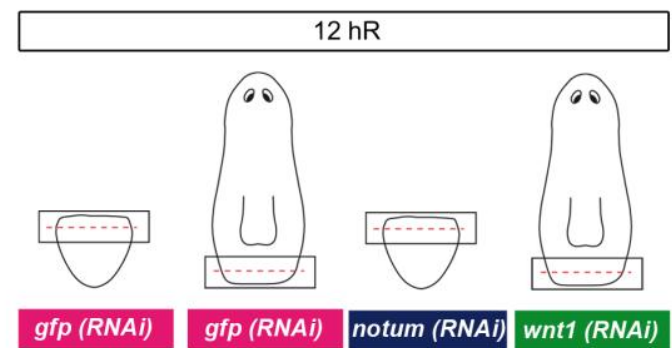

P Active enhancers
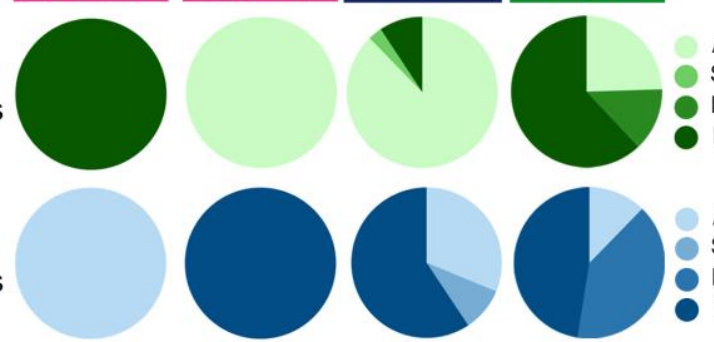

Accessible

Slighly accessible

Less accessible

Non-accessible

A Active enhancers
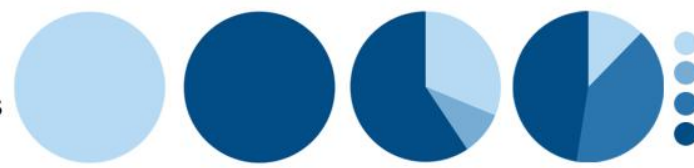

Accessible

Slighly accessible

Less accessible

Non-accessible
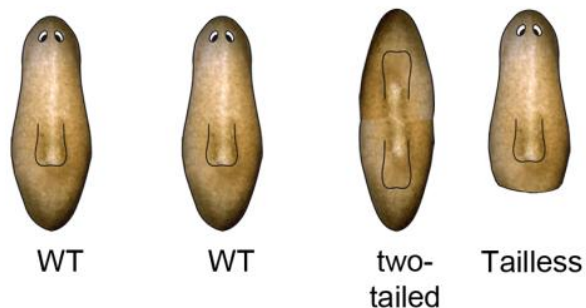

Tailless

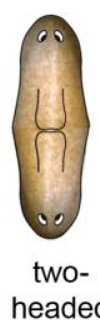

Figure 1. At 12 hours of regeneration anterior and posterior wounds show a specific remodelling of the chromatin. a Workflow to identify specific anterior and posterior specific enhancers at $12 \mathrm{hR}$. Next to each workflow step, the program used is indicated. $\mathbf{b}$ Accessibility changes of the anterior and posterior specific active enhancers after notum and wnt1 inhibition at $12 \mathrm{hR}$ are represented in percentages in pie charts. Schematic illustration shows the representative phenotypes observed during regeneration after each gene inhibition. $\mathrm{hR}$, hour of regeneration.

Furthermore, the results show that inhibition of the key elements of the anterior and posterior organizers, notum and wnt1, respectively, produces a very early change of the chromatin structure, suggesting that both elements trigger the specific anterior or posterior program through the regulation of chromatin remodelers. The chromatin changes in notum (RNAi) wounds with respect to wt, are much stronger that in wnt1 (RNAi). This could reflect an earlier role of notum in specifying polarity. But it could be also explained because in our experimental conditions notum (RNAi) animals polarity is changed, they became two-tailed, while most of wnt1 (RNAi) animals will became tailless, showing no posterior regeneration, 
which is the mild wnt1 (RNAi) phenotype $(21,43)$, and only $10 \%$ change polarity and become two-headed.

\section{Homeobox TFs motives are found enriched in Cis Regulatory Elements of genes downregulated in wnt1 RNAi planarians and, in turn, contain TCF binding sites.}

To identify CREs that could be regulated by the cWNT pathway during posterior regeneration we first performed an RNA-seq of controls and wnt1 (RNAi) posterior wounds ( 0 to $72 \mathrm{hR}$ ) to find the genes downregulated after cWNT pathway inhibition. We performed differential expression analysis (padj $<0,05, \mathrm{fc}>0,5)$ at each time point (Table S2). 2129 genes were found to be differentially expressed at any time point; among them 712 genes were down-regulated in wnt1 (RNAi) planarians with respect to controls (Figure 2B and Table S2). The posterior Homeobox genes are found in the list of down-regulated genes (Smed-hox4b, Smed-post-2c Smed-post-2b, Smed-lox5a and Smed-lox5b), as well as the posterior Wnts11 (wnt11-1 and wnt11-2) $(43,45)$, the posterior Frizzled $f z d 4$ and sp5, the TF recently found to mediate the evolutionary conserved role of cWNT in axial specification (46). Interestingly, the TFs required for regeneration of longitudinal and circular fibers, myoD and $n k x-1$, respectively (19), are also found among the wnt1 RNAi downregulated genes, which could account for the rounded shape of the Tailless posterior tip.

To analyse the CREs of the wnt1 RNAi down regulated genes we first identified the CREs found in planarian wounds $(0-48 \mathrm{hR})$ using the previous ATAC-seq and CHIPmentation samples, in addition to new ATAC-seq analysis of 0 and $48 \mathrm{hR}$ wounds (https://compgen.bio.ub.edu/PlanNET/planexp). We classified the CREs found in Promoters or Enhancers according to their position with respect the Transcriptional start site (TSS) (Figure 2A) (defined in Material and Methods section). Promoters were classified in Core Promoters (CP) and Proximal Promoters (PP), and we identified 2594 and 1549 of each, 
bioRxiv preprint doi: https://doi.org/10.1101/2020.12 08.416008; this version posted December 9,2020 . The copyright holder for this preprint (which was not certified by peer review) is the author/funder, who has granted bioRxiv a license to display the preprint in perpetuity. It is made available under aCC-BY-NC-ND 4.0 International license.

respectively. Enhancers were classified in First Intron (FI) Proximal (Pro) and Distal (Dis), and we identified 3157,19610 and 28720 of each, respectively.

a

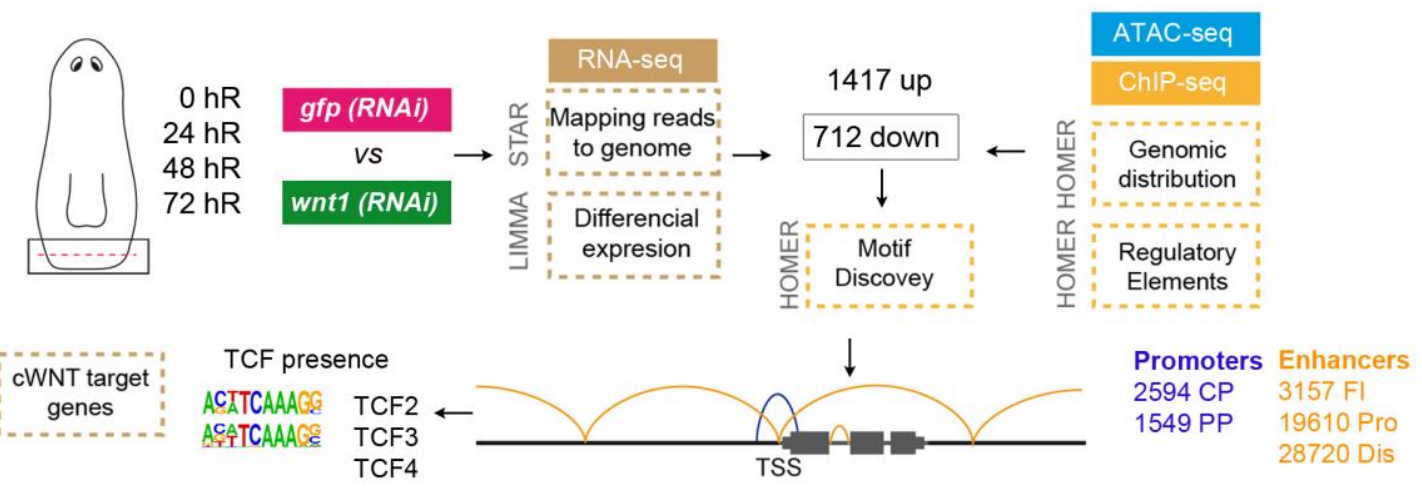

b

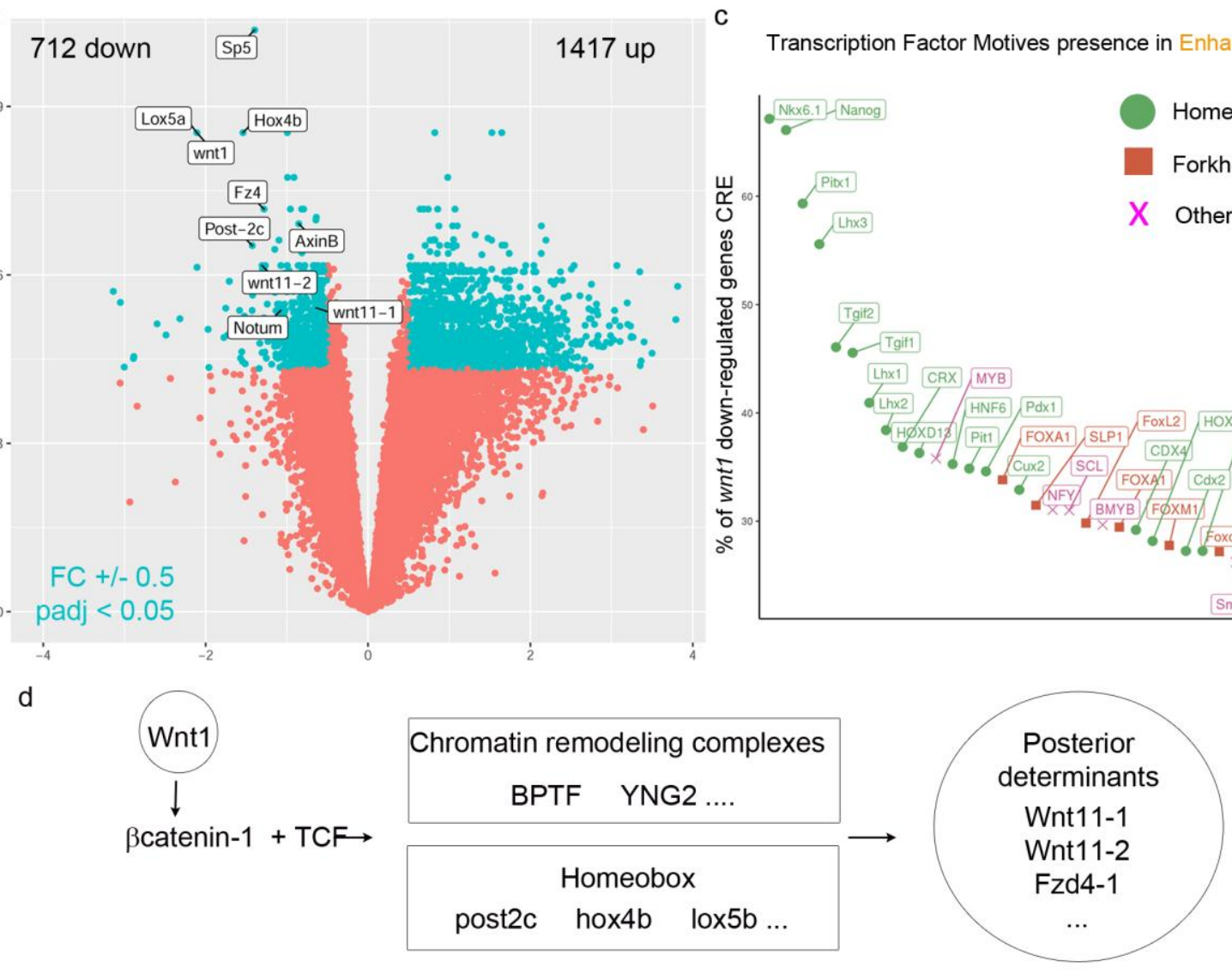

Figure 2. Cis-regulatory regions found in genes down-regulated after wnt1 RNAi. a Workflow to identify differentially expressed genes, cis regulatory elements (CRE) and transcription factors associated to wnt1 (RNAi). Next to each workflow step, the program used was indicated. Motif discovery for TCF binding site were specifically performed in down-regulated wnt1 (RNAi) genes. b Volcano plot shows the down- and up-regulated genes after wnt 1 inhibition which present fold change (FC) +/- 0.5 and pValue adjusted (padj) <0.05. c Motif enrichment of the CRE of wnt1 (RNAi) down- 
regulated genes, showing an enrichment for homeobox motives. d Schematic illustration of the proposed genetic program activated by wnt 1 in posterior wounds.

Using HOMER we could analyze the presence of TF binding motifs in the CREs of the 712 genes down-regulated in wnt1 (RNAi) wounds. The result shows that the overrepresented motifs mainly bind Homeobox TFs (Figure 2C). Considering that posterior identity is specified by the cWNT signalling (Wnt1- $\beta$ catenin-1 -TCF) (47), we then searched for the CRE containing a TCF binding site. We found 167 genes containing a TCF binding site in the enhancer, 17 of which also showed a TCF motif in the promoter (Table S3). Among them, we found the genes already known to be involved in $\mathrm{P}$ specification: posterior Hox genes (lox5b, hox4b, post2c) (26), sp5 (46), axinB (24) and tsh $(37,38)$, indicating that they are direct targets of the Wnt1- $\beta$ catenin-1 -TCF signalization. We also combined our RNAseq data with the RNA-seq of $\beta$ catenin-1 RNAi animals already reported (46). This strategy ended up with 42 genes (Table S2), which included most of the posterior genes already found to possess a TCF binding site, further supporting the direct role of these candidates in specifying posterior through the cWNT signalling. A new web-tool has been developed in order to search for transcription factor binding sites and to explore the newly predicted regulatory elements (https://compgen.bio.ub.edu/PlanNET/tf tools).

As exposed, several genes downregulated in wnt1 (RNAi) wounds showed a TCF binding site. However, the overrepresented motives found in wnt1 (RNAi) downregulated genes are not TCFs but Homeobox. These results suggest that the Wnt1- $\beta$ catenin-1-TCF signal could directly activate the expression of Homeobox TFs, which in turn will activate the determinants of the posterior fate. In effect, analyzing the list of genes with TCF binding site we found several Homeobox TFs downregulated after wnt1 (RNAi) in addition to the ones already reported (hox4b, lox5b or Post2c), as BARHL2 or NKX6-2. Among the wnt1 (RNAi) downregulated genes containing TCF motives we also found chromatin remodelling complexes, as BPTF, a nucleosome-remodeling factor (48), and YNG2, which acetylates 
bioRxiv preprint doi: https:/doi.org/10.1101/2020.12.08.416008; this version posted December 9, 2020. The copyright holder for this preprint (which was not certified by peer review) is the author/funder, who has granted bioRxiv a license to display the preprint in perpetuity. It is made available under aCC-BY-NC-ND 4.0 International license.

nucleosomal histone $\mathrm{H} 4$ and $\mathrm{H} 2 \mathrm{~A}$ (49)(Figure 2D). This result agrees with the rapid changes in chromatin conformation that we have observed at $12 \mathrm{~h}$ of regeneration.

Overall, we have identified new genes, TFs and CREs participating in the specification of posterior identity; some of them were already known to specify posterior, validating our strategy, and many of them are new elements of the Wnt1 gene regulatory network. Our data suggests that Wnt1-ßcatenin-1-TCF signal directly activates chromatin remodelling complexes and Homeobox genes which in turn regulate the determinants of posterior specification.

\section{FOXG could regulate wnt1 transcription and specify posterior identity through} binding to a Cis-regulatory element (CRE) found in wnt1 first intron.

Taking advantage of the previous analysis that allowed the mapping of CRE in $S$. mediterranea genome (39), we sought to investigate the presence of CRE in the wnt1 locus, in order to understand the regulation of its expression. We found different evidences that the first intron of wnt1 presented two enhancers, which were named enhancer 1 (E1) and enhancer 2 (E2) according to their distance to the TSS (Figure 3a and Supp data1). We found that both regions show: (i) a nucleosome free region (ATAC-seq peak) and (ii) that this region is surrounded by histone modifications related with enhancer activity (H3K27ac ChIPmentation) (Figure 3a). Both putative enhancers were located less than $3 \mathrm{~kb}$ away from the wnt1 promoter suggesting that they could regulate its expression (50). Trough motif discovery we analysed the presence of TF binding sites in both regions, and we observed the presence of FOXG binding sites (Figure 3a and Supp data1).

To further investigate whether FOXG could be regulating wnt1 expression we inhibited it by RNAi in regenerating animals (Figure $3 \mathrm{~b}$ ). ISH of wnt 1 in foxG (RNAi) animals demonstrated that it was absent both at $12 \mathrm{hR}$ and $3 \mathrm{dR}$ posterior wounds, indicating that foxG is required for both the early (stem cell independent) and the late (stem cell dependent) phase of wnt 1 expression (Figure 3c). foxG was also necessary for the expression of wnt1 in the anterior $12 \mathrm{hR}$ wounds (Figure 3c). This result is important, since it is the first gene reported to date 
bioRxiv preprint doi: https://doi.org/10.1101/2020.12 08.416008; this version posted December 9,2020 . The copyright holder for this preprint (which was not certified by peer review) is the author/funder, who has granted bioRxiv a license to display the preprint in perpetuity. It is made available under aCC-BY-NC-ND 4.0 International license.

that regulates the early wnt 1 stem cell independent expression that occurs few hours after amputation in any wound. Furthermore, inhibition of foxG in intact animals also lead to the disappearance of wnt1 expression (Figure S1), supporting its general role for the expression of wnt 1 in planarians, possibly by binding to the enhancer found in the first intron of wnt 1 .

a

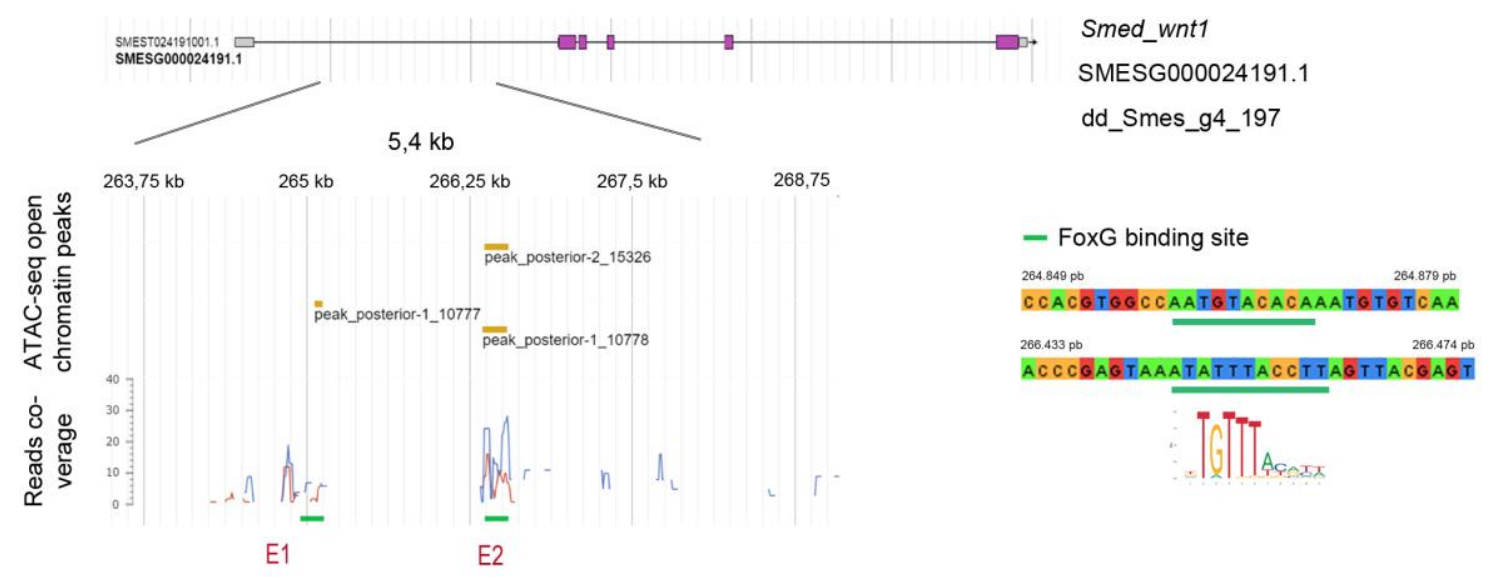

b

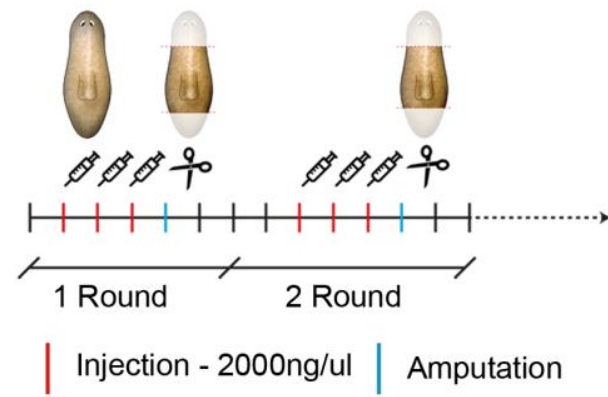

d

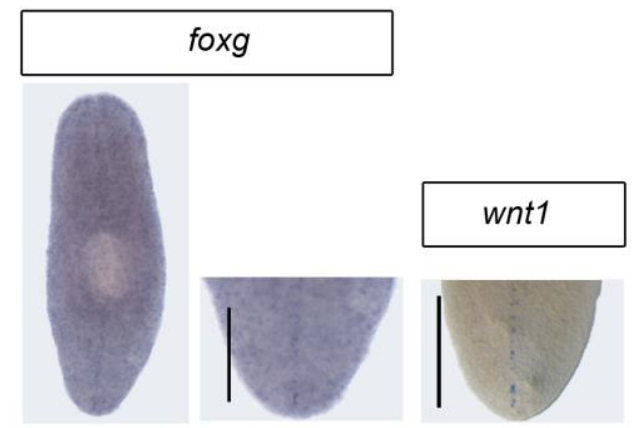

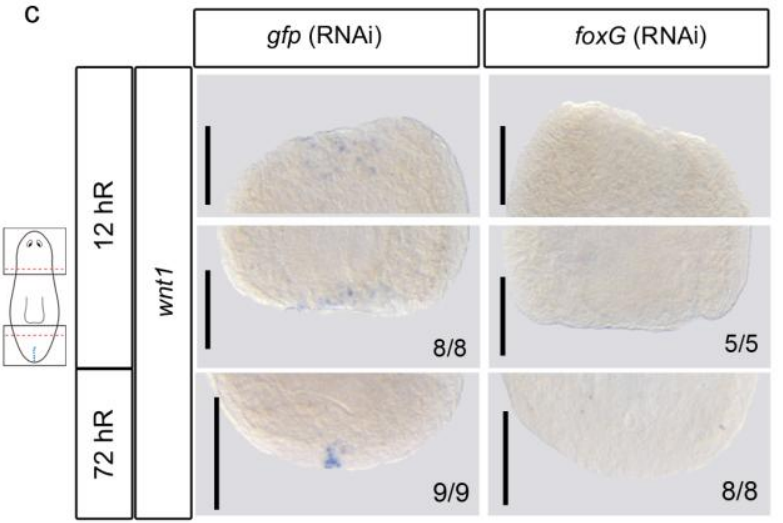

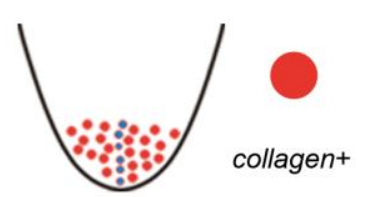

Figure 3. FoxG could bind to a wnt1 enhancer to regulate wnt1 transcription. a Schematic illustration of Smed-wnt1 gene locus, indicating exons (violet boxes) linked by introns (lines). Enhancers are named E1 and E2, FOXG motif (slp1) was present in both enhancers (green line). The ATAC-seq peaks corresponding to the E1 and the E2 are indicated. $\mathbf{b}$ Schematic illustration indicating the foxG RNAi procedure. c ISH of wnt1 in foxG (RNAi) animals demonstrate its absence in regenerating blastemas both at 12 and $72 \mathrm{hR}$. Schematic illustration of wnt 1 in intact animals and the analysed 
zones (squares) was added. d WISH of foxG in intact animals shows its expression in the posterior midline, as wnt1. Single cell analysis performed by (41) showed six genes (top 16\%) over represented in posterior organizing wnt1+ cells. Among them foxG was found. Scale bar: $100 \mu \mathrm{m}$ in c; $200 \mu \mathrm{m}$ in d.

In agreement with a direct role of foxG in regulating wnt1 expression and posterior specification, ISH analysis shows that foxG is expressed in the posterior dorsal midline, as described with wnt1 expression (Figure $3 d$ ). foxG is also expressed in cells along the D/V margin, and in some scattered cells in the dorsal and ventral part of the animals. Single Cell Sequencing (SC-seq) databases analysis indicates that those cells could be muscular and neuronal (Figure 3d and Figure S21). To note, foxG is one of the specific genes found in muscular wnt $1+$ cells of the posterior midline (wnt1+ and collagen+) in intact animals and in posterior regenerating blastemas at $72 \mathrm{hR}(51,52)$, further supporting its essential role in the specification of the posterior organizer (Figure 3d).

If foxG is required for wnt 1 expression, then regenerating foxG (RNAi) animals should show a phenotype related with the malfunction of the posterior organizer. Accordingly, we found that $70 \%$ of foxG (RNAi) animals presented a rounded posterior blastema, resembling the tailless phenotype obtained in the mild wnt1 RNAi phenotype (Figure 4a). Analysis of the central nervous system and the digestive system by anti-arrestin (3C11) and anti- $\beta$ cat-2 immunohistochemistry, respectively, demonstrated that these $70 \%$ animals are tailless (Figure $4 b$ and Figure S2b). They show a fusion of the posterior nerve cords and intestine branches in $U$ shape, as it has been described after inhibition of other key posterior genes such as wnt1 $(21,43)$, wnt11-2 $(29,43)$, islet $(35,36)$ or pitx $(36)$. Furthermore, ISH with posterior markers, which we demonstrate in the previous section are cWNT target genes (fz4, post2d, sp5 and hox4b) demonstrates that they are downregulated in posterior foxG (RNAi) blastemas at $3 \mathrm{dR}$ (Figure $4 \mathrm{~b}$ ). Eventually some animals showed the strongest two- 
bioRxiv preprint doi: https:/doi.org/10.1101/2020.12.08.416008; this version posted December 9, 2020. The copyright holder for this preprint (which was not certified by peer review) is the author/funder, who has granted bioRxiv a license to display the preprint in perpetuity. It is made available under aCC-BY-NC-ND 4.0 International license.

headed phenotype (Figure 4a). Synapsin analysis demonstrates the appearance of a posterior brain in these animals (Figure 4c).
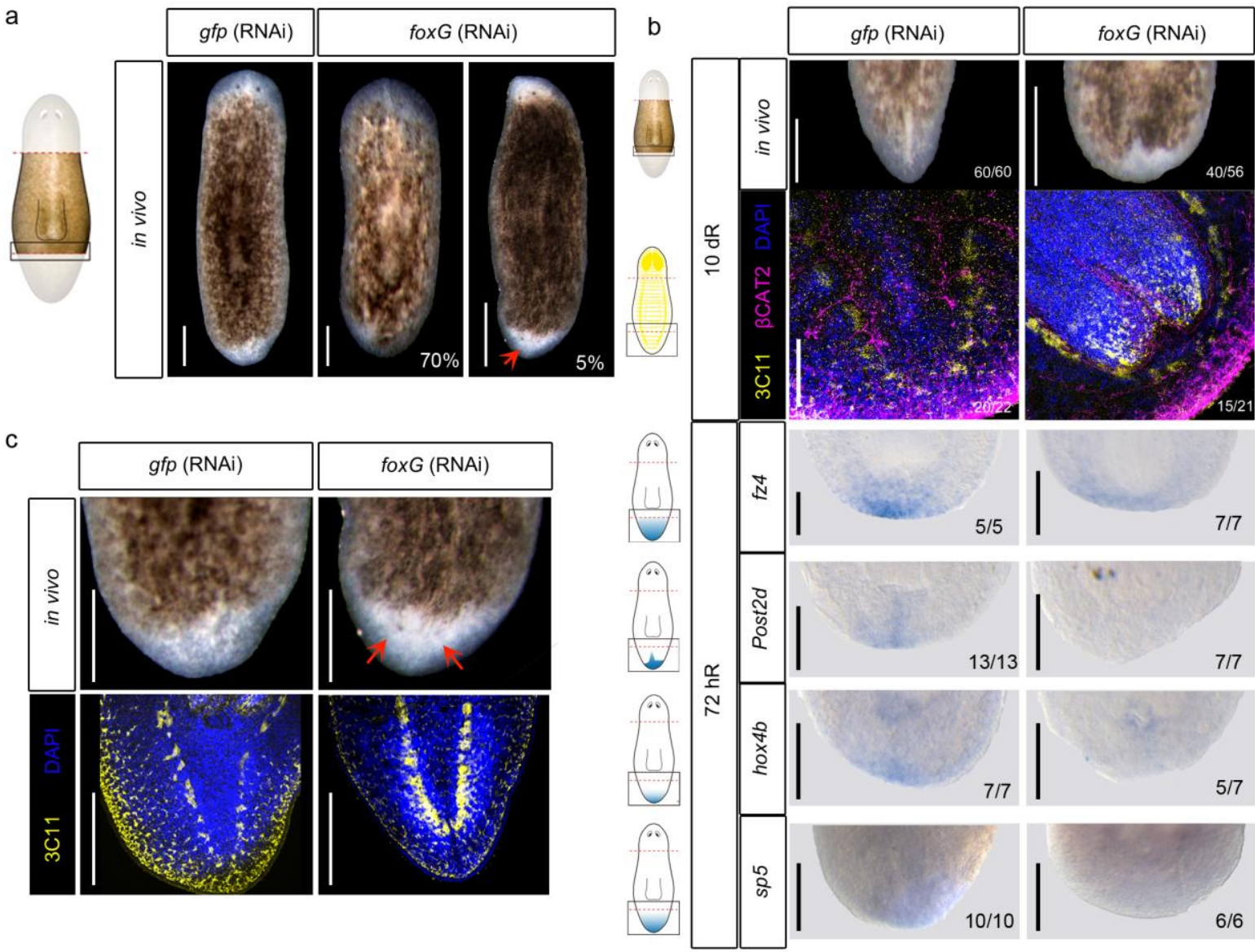

Figure 4. foxG RNAi phenocopies wnt1 inhibition. a in vivo phenotypes after foxG (RNAi). b Immunostaining using $\alpha$-SYNAPSIN (3C11) (neural system) and $\alpha-\beta C A T 2$ (digestive system) reveal rounded ventral nerve chords in foxG (RNAi) compared to peak shaped gfp (RNAi) animals. Nuclei are stained in DAPI. WISH of posterior markers in regenerating foxG (RNAi) animals demonstrated a reduced expression. Schematic illustrations of posterior markers were added. c Immunostaining using a-SYNAPSIN (3C11) (neural system) reveal a posterior brain in the foxG (RNAi) Two-headed animals. Nuclei are stained in DAPI. Posterior eyes are indicated with a red arrow in a and c. Posterior eyes are indicated with a red arrow in a and c. Scale bar: $100 \mu \mathrm{m}$ in a, immunostaining in b and c: $200 \mu \mathrm{m}$ in WISH in b.

All together, these results demonstrate that foxG is a new element of the posterior organizer. Our data indicates that foxG is upstream of wnt 1 because inhibition of foxG suppresses wnt 1 expression in all stages and tissue regions, and because wht1 (RNAi) animals do not show a decrease in foxG expression (Table S2 and Figure S2c). 
Although our data does not demonstrate the direct binding of FoxG to the enhancer found in the first intron of wnt1, we looked for evidences showing the evolutionary conservation of this enhancer. Interestingly, we found that the position of Schmidtea mediterranea intron 1 is highly conserved through evolution (Fig 5). wht1 genes present a variable number of introns, however, the first intron, which contains the FoxG binding site, maintains a conserved position in all the genomes analysed (Fig 5a and Table S4). Furthermore, the analysis of reported ATAC-seq data demonstrates the existence of chromatin open regions in this intron (Fig 5 and Table S4). More importantly, in Drosophila melanogaster there is a CHIPmentation analysis using the FoxG antibody that demonstrates the binding of DmFoxG (slp1) in the first intron of Dm-wnt1 $(53,54)$.

Thus, our data supports the hypothesis that in planarians FoxG could directly regulate wnt1 expression, and the early establishment of the posterior organizer, through binding to a first intron enhancer.

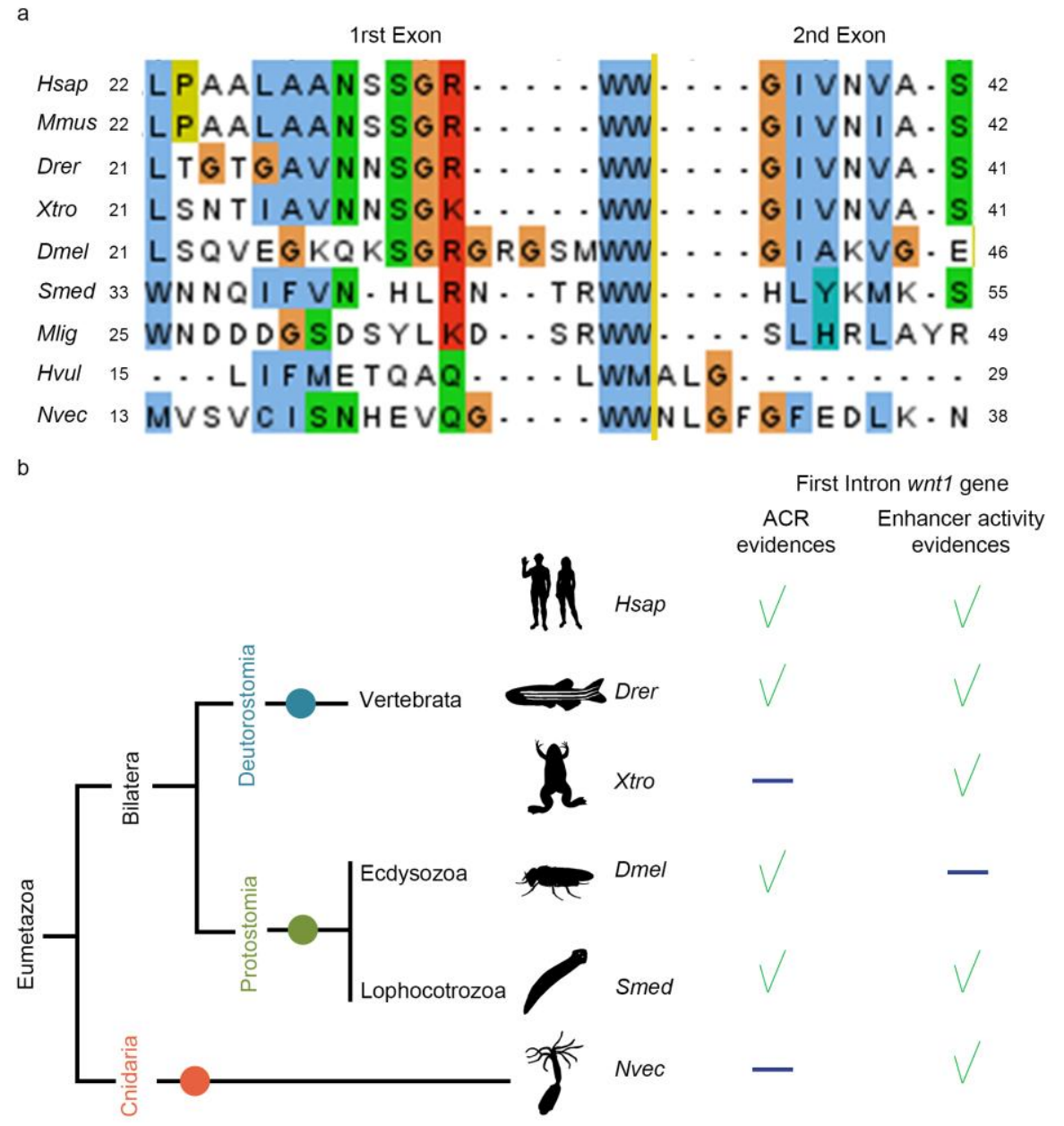


Figure 5. Enhancers located in the first intron of wnt1 are conserved thought evolution. a Alignment of WNT1 amino acid sequences from Homo sapiens (Hsap), Mus musculus (Mmus), Danio rerio (Drer), Xenopus tropicalis (Xtro), Drosophila melanogaster (Dmel), Schmidtea mediterranea (Smed), Macrostumum ligano (Mlig), Hydra vulgaris (Hvul) and Nematostella vectensis (Nvec) showing high level of conservation on the position of intron 1. Yellow line shows the separation between the first and the second exon. b Schematic summary of accessible chromatin regions (ACR) and enhancer activity evidences in the first intron of wnt 1 genes in different metazoan species. Green tick indicates evidences and blue line indicates no available data.

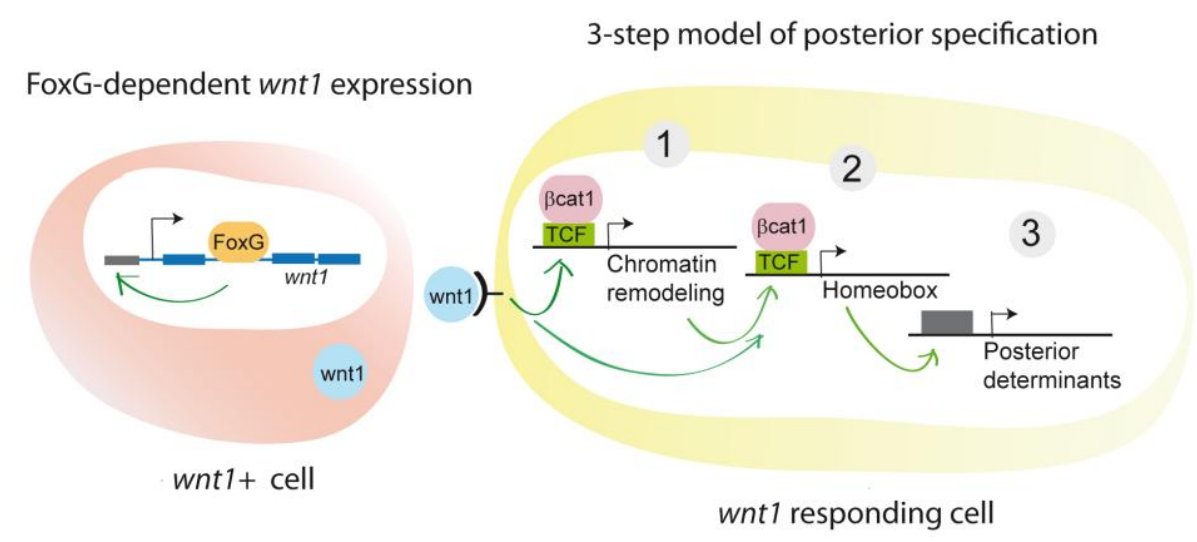

Figure 6. 3-step model of posterior specification.

\section{Discussion}

Dynamics of genomic and transcriptomic changes occurring during posterior identity specification

The plasticity of planarians is providing insightful data about the mechanism underlying regeneration. Several studies now demonstrate that the anterior and the posterior tips of planarians function as organizers, a term that has been traditionally used in the field of embryonic development. The finding of adult organizers in other regenerating animals as hydra, zebrafish or xenopus tadpoles supports the idea that the formation of organizers could be a general mechanism that confers regenerative properties (55-57) There are common features in the reported examples: 1) the cells that function as organizers are nonproliferative and are located in the periphery of the early blastema, 2) the organizing activity relies of the cWNT signal $(55,56,58)$. These properties are also accomplished by planarian 
bioRxiv preprint doi: https:/doi.org/10.1101/2020.12 08.416008; this version posted December 9, 2020. The copyright holder for this preprint (which was not certified by peer review) is the author/funder, who has granted bioRxiv a license to display the preprint in perpetuity. It is made available under aCC-BY-NC-ND 4.0 International license.

organizers. A difference between planarians and other bilaterian models of regeneration is that planarians can completely regenerate a new axis from both ends, anterior or posterior, independently of the fragment amputated. This plasticity, together with the use of genomic and transcriptomic high throughput techniques, has allowed us to compare the genomic changes occurring during anterior or posterior specification in the same field of original cells. Our data indicates that the establishment of the appropriate identity in a planarian wound could follow the following 3 steps (3-step model in Figure 6 ). $1^{\text {st }}$ ) remodelling of the chromatin, which must occur very early after a cut, even before the appearance of any anterior or posterior marker. We demonstrate that the regulation of the cWNT signal is fundamental for this remodelling. We have seen a strongest contribution of notum in anterior wounds than wnt 1 in posterior wounds in this remodelling. However, we cannot conclude that notum has a more determinant or earliest effect than wnt1, since we only have analyzed one time point, 12 hours after the cut, and furthermore our wnt1 (RNAi) animals have a milder phenotype (Tailless) than notum RNAi animals (Two-tailed). $2^{\text {nd }}$ ) Remodelling of the chromatin could allow the expression of polarity genes, as the Hox genes, which expression has shown to be dependent on extensive chromatin remodelling in other models (59). $3^{\text {rd }}$ ) Hox genes among others would allow the transcription of the Posterior determinants, which are the effectors required to differentiate tail structures.

The early change in the genomic landscape found in each regenerating tip, together with the finding of several chromatin remodelling proteins down-regulated in wnt1 (RNAi) genes showing a TCF binding site (refs) indicates that in planarians the Wnt/ $\beta$-catenin pathway specifies cell fate through regulating chromatin structure and reprogramming as described in other contexts (60). It is important to note that the early expression of notum and wnt 1 is stem cell independent (22), supporting the important role that reprogramming could have at this early stages. Importantly, our data restricts the timing when this chromatin remodelling it is happening, which must be earlier than 12 hours after the cut. Thus, a novelty of the proposed 3-step model is that, in contrast to the results found in previous transcriptomic 
analysis in planarians, in which injury-specific transcriptional responses emerged 30 hours after injury (44), we have observed that changes occurring in the chromatin of cells in each wound are wound-specific and occur few hours after the cut. These rapid changes at genomic level have been visualized thanks to the genomic analysis restricted to the cells in the wound region and at a very early time point $(12 \mathrm{hR})$, much before the appearance of any polarity signal.

Our RNA-seq analysis agrees with previous transcriptomic studies, since we have found that inhibition of wnt1 leads to the deregulation of a large number of genes at late time-points (48-72h), corresponding to the previously called injury-specific transcriptional response (44) . However, the second novelty of our 3-step model is that through the identification of the CREs in Smed genome, we could observe only few wnt1 (RNAi) down-regulated genes containing TCF motives in their CREs, and many of them correspond to chromatin remodelling complexes and homeobox proteins. This result suggests that Chromatin remodelling proteins and Homeobox genes are direct targets of WNT1 that afterwards will activate the transcription of the posterior determinants. The Hox genes post2c, lox $5 a / b$ and hox $4 b$ are specifically expressed in posterior, although regenerative deflects have only been see after lox5a (RNAi) $(45,46)$. Not only in planarians but also in other whole body regenerating animals as acoels and hydra Hox genes and sp5, which also shows a TCF motive in its CRE, are the conserved set of cWNT targets that mediate the patterning of the primary body axis $(46,58)$.

According to our data, wnt11-1 and wnt11-2, which are required to regenerate a proper tail but whose inhibition never produces a shift in polarity $(21,22,43)$, are down-regulated at late stage in wnt1 (RNAi) animals, and do not show a TCF binding motive in their CRE, suggesting that they could be part of what we have called the Posterior effectors. Supporting the late role of wnt11-1 and wnt11-2, their silencing inhibits the late wnt1 expression but not the early one (43). The same situation is found with the posterior expressed WNT receptor, $f z d 4$. In this case, it could be that the expression of $f z d 4$ is mediated by the first $w n t 1+$ cells 
bioRxiv preprint doi: https:/doi.org/10.1101/2020.12.08.416008; this version posted December 9, 2020. The copyright holder for this preprint (which was not certified by peer review) is the author/funder, who has granted bioRxiv a license to display the preprint in perpetuity. It is made available under aCC-BY-NC-ND 4.0 International license.

forming the posterior organizer, in accordance with the idea that organizers evocate the surrounding tissue; a first organizer action would be to prepare the tissue to make it competent to itself (2).

\section{Establishment of the posterior organizer requires a FOXG mediated WNT1 signal}

The fundamental role of the Notum-Wnt1 antagonism in establishing the identity of a wound has been widely demonstrated through functional and expression analysis $(20-22,43)$. The proposed 3-step model assumes this antagonism and presupposes that the remodelling of the chromatin is different in anterior and posterior wounds because notum is expressed at higher levels in anterior and wnt1 is expressed at higher levels in posterior. Genes required for the late expression of notum and wnt1, localized in the midline, have been identified. foxD and zicA RNAi animals do not show the late expression of notum and do not regenerate a proper head (30-32); islet and pitx for RNAi animals do not show the late expression of wnt1 and are Tailless $(35,36,61)$. However, the regulation of the expression of notum and wnt 1 in a salt and pepper manner in early wounds and their final restriction to the anterior and posterior pole, respectively, remained unsolved.

Thanks to the annotation of the CREs in the planarian genome, we could identify an enhancer in the first intron of wnt1 gene which showed FOXG binding motives. We propose that these CREs are general enhancers required for wnt1 expression in planarians. First, they are localized in the first intron, which is a region frequently enriched in regulatory elements (62-65); second, we have found that foxG is necessary for wnt1 expression in any context. foxG inhibition suppresses the early and the late phase of wnt 1 expression during regeneration, as well as its expression during homeostasis. And third, it could be evolutionary conserved, which further supports its relevance. We have found that the position of intron 1 in all wnt 1 genes studied from different metazoans species is extremely conserved. Furthermore, there are several genomic studies that demonstrate the existence of open regions in this intron, and a Chip-sequencing analysis with the FoxG antibody in 
bioRxiv preprint doi: https:/doi.org/10.1101/2020.12.08.416008; this version posted December 9, 2020. The copyright holder for this preprint (which was not certified by peer review) is the author/funder, who has granted bioRxiv a license to display the preprint in perpetuity. It is made available under aCC-BY-NC-ND 4.0 International license.

Drosophila demonstrates that foxG binds to Dm-wnt1 (wingless) intron 1. We hypothesize that the binding of FoxG to the intron 1 of wnt1 to regulate its expression is ancestral and has been conserved through evolution. Genomic studies in different regenerative species have identified different sets of TFs as regulators of cWNT genes during regeneration. In Drosophila, injured imaginal disc required 'regenerative enhancers' to trigger wingless expression and the regeneration process (66-68). During Hydra head regeneration, an enhancer collection become accessible allowing the expression of cWNT genes in head organizing cells $(69,70)$. In acoels, egr is expressed after amputation triggering the expression of wnt3, which participates in the posterior specification $(67,71)$. As recently proposed, it could be that enhancers may be maintained as part of conserved gene regulatory network modules over evolution (72). In this respect, further studies are required to analyse the evolutionary conservation of the enhancers found in the first intron of wnt1.

RNAi inhibition of foxG suppresses both early and late wnt1 expression after amputation, and, consequently, animals became Tailless. Importantly, in a low percentage, foxG (RNAi) animals regenerated as Two-headed. A shift in polarity is a phenotype only found after Bcatenin1 or wnt1 RNAi $(21,24,28)$, but never after islet or pitx RNAi. Thus, the finding of Two-headed foxG (RNAi) animals, suggests that inhibition of the late phase of wnt1 prevents the regeneration of a tail, but that inhibition of the early phase is required to shift polarity. This idea is supported by the reports on the role of $\mathrm{Hh}$ signal in planarians. Activation of the hh signal is also required for the early phase of wnt 1 expression and in a low percentage animals become two-headed $(73,74)$. According to these data, Hh could mediate its early role in polarity establishment by regulating wnt1 expression through foxG activation, as it has been reported in zebrafish and mouse, where Hedgehog signalling contributes to Foxg1 induction and integration of telencephalic signalling centres $(75,76)$.

The planarian posterior organizer is defined by the expression of wnt 1 in differentiated muscular cells. However, the cells in the organizer must integrate a signalling network which includes several genes which are not cell specific, and simultaneously they must be 
integrated in a diverse a dynamic cellular context. Our study has provided some light to this genetic and cellular context of the planarian posterior organizer. We have found foxG as a gene essential for wnt1 expression, which inhibition phenocopies wnt1 RNAi. However, foxG is not specifically expressed in wnt $1+$ muscular cells, but it is also expressed in neurons and in progenitor cells. In fact, we have found that the binding site for FoxG (SLP1) was also notably enriched in enhancers of wnt1 (RNAi) down-regulated genes. Thus, FoxG could regulate not only wnt1 expression in muscular cells but additional wnt1 regulated posterior genes in other cell types, as neurons. Further studies are necessary to analyze whether FoxG binds to E1 and/ or E2 of Smed wnt1, as well as the existence of specific co-factors that confer it a cell-dependent activity.

\section{Conclusion}

The existence of 'regenerative enhancers', groups of enhancers that become accessible during regeneration, has been demonstrated in regenerating species as zebrafish and Drosophila imaginal discs $(66,77-80)$. The plasticity of planarians, which make possible the comparative study of anterior and posterior regenerating wounds originating from the same field of cells, has allowed the identification of 'regenerative enhancers' specifically associated to the posterior specification. The data presented in this study suggests that the formation of the posterior organizer could be working as a chain reaction. A first differential signal in the wound according to the polarity of the pre-existent tissue (which could be related to Hh or other neural signals) $(73,74)$ would lead to the rapid resolution of the NotumWnt1 antagonism, which in posterior wounds will maintain Wnt1 and suppress Notum. At this point, which must occur during the first 6 hours the program to become posterior has already started, setting up chromatin changes specific to the posterior pole and dependent on cWNT activation. Chromatin conformation changes would allow the subsequent expression of a specific set of TFs that will turn on the tail effectors. 
Organizers or organizing centers are required for growth and pattern of a new structure and are well studied during embryonic development. However, in whole-body regenerating animals as planarians or hydra, organizers are also found in adults. Muscular wnt $1+$ cells are found in the midline of posterior wounds and in the tail of planarians during homeostasis $(22,29)$, and we have found that in both contexts wnt1 expression depends on foxG. However, homeostatic and regenerating wnt1+ cells have different properties, since inhibition of wnt1 or foxG during homeostasis never produces a shift in polarity. After an amputation, when new tissue must be regenerated, there must be a time window when everything is possible. According to the signal received by the cells in the wound the identity of the organizer will be decided. Importantly, not only the identity but the presence of an organizer, which means the possibility to regenerate or not, will be determined. This was shown in Liu et al. when modulating the cWNT provided regenerative capacity to planarian species that are not able to regenerate a head in nature (81). These results indicate that the ability to form an organizer is linked to the ability to regenerate. Thus, understanding the formation and function of Organizers is key to understand adult regeneration.

Finally, our results demonstrate the power of genome wide approaches to further understand the genetics of regeneration. With the aim to share the results obtained in this study and to facilitate their further analysis to the scientific community, we have created a new open platform to query and interpret all transcriptomic and genomic results obtained (https://compgen.bio.ub.edu/PlanNET/planexp). Furthermore, an additional web-tool has been developed in order to search for transcription factor binding sites and to explore the newly predicted regulatory elements (https://compgen.bio.ub.edu/PlanNET/tf tools).

\section{Material \& Methods}

\section{Planarian husbandry}


Schmidtea mediterranea clonal strain $\mathrm{BCN}-10$ animals were starved for at least 7 days prior any conducted experiment. Asexual animals were cultured in glass containers and Petri dished for experiments in PAM water (82) at $20^{\circ} \mathrm{C}$ the dark. Animals were regularly feed twice per week with organic cow liver (83).

\section{RNAi experiment design}

For RNAi, double strand RNA (dsRNA) was synthesised by in vitro transcription (Roche) using PCR-generated templates with T7 and SP6 flanking promoters. Precipitation step was carried using ethanol, followed by annealing and resuspension in water. (92). dsRNA (3 × $32.2 \mathrm{nl}$ ) was injected into the digestive system of each animal on 3 consecutive days (1 round). For wnt1 RNA-seq samples, inhibited and control animals were injected one round at $1500 \mathrm{ng} / \mu \mathrm{l}$ and amputated at post-pharyngeal level. Then, studied pieces were soaked in dsRNA diluted in PAM water for 3 hours in the dark. For wnt1 and notum ATAC-seq samples, inhibited and control animals were injected two rounds at $1000 \mathrm{ng} / \mu \mathrm{l}$ and amputated at pre- and post-pharyngeal level. foxG RNAi regenerating animals were inhibited two rounds and amputated at the end of each round; and intact animals were inhibited for three consecutive rounds. All control animals were injected and/or soaked with dsRNA of GFP.

\section{Assay for transposase-accessible chromatin sequencing (ATAC-seq)}

ATAC-seq samples were obtained from the wound region of wild type, notum (RNAi), wnt1 (RNAi) or gfp (RNAi) samples. Planarian mucous was removed by washing in $2 \%$ L-Cystein $(\mathrm{pH} 7)$ for 2'. Afterwards, animals were transferred in a petri dish with $\mathrm{CMFH}(2.56 \mathrm{mM}$ $\mathrm{NaH} 2 \mathrm{PO} 4 \times 2 \mathrm{H} 2 \mathrm{O}, 14.28 \mathrm{mM} \mathrm{NaCl}, 10.21 \mathrm{mM} \mathrm{KCl}, 9.42 \mathrm{mM}$ NaHCO3, 1\%BSA, 0.5\%Glucose, $15 \mathrm{mM}$ HEPES $\mathrm{pH}$ 7.3). Planarians were placed in Peltier Cells at $8^{\circ} \mathrm{C}$ to amputate the wound region (the blastema and post blastema region posterior to the mouth). Then, transferred to an $1.5 \mathrm{ml}$ Eppendorf tube to be dissociated using a solution of liberase/CMFH 
(1:10) at RT for 10 minutes. Twenty animals were used per biological replicate. ATACsequencing was carried out as first described in (84) and then adapted by (85).

\section{ChIPmentation}

ChIPmentation combines ChIP with library preparation using Tn5 transposase, similar to ATAC-sequencing. ChIPmentation samples were obtained from the wound region of wild type animals. Planarians were placed in Peltier Cells at $8^{\circ} \mathrm{C}$ to amputate the wound region (the blastema and post blastema region posterior to the mouth). Then, wounds were transferred to a Petri dish containing $1 \mathrm{M} \mathrm{MgCl} 2$ solution, for $15-30$ " rocking at RT. PBS $1 \mathrm{X}$ was added to remove salts. Blastemas were fixed with formaldehyde $1,85 \%$ for $15^{\prime}$ rocking, at RT. Glycine was added to obtain a final concentration of $0.125 \mathrm{M}$ to quench formaldehyde, for 5' at RT, rocking. Then, blastemas were washed 3X with cold PBS1X. Finally, PBS excess was removed, and samples were stored at $-80^{\circ} \mathrm{C} .2000$ anterior and posterior blastemas were used. Groups of 100 blastemas were done at a time. ChIPmentation was carried out as described in (86).

\section{ATAC-seq and CHIPmentation analysis}

Reads were aligned using bowtie1 using -m 3 -k 1 arguments. Bam reads were filtered using a $<=100$ bp insert size threshold to identify nucleosome free regions (NFR) (87). Bam files were converted to bed and then the coordinates were shifted +4 and -5 positions to overcome the Tn5 cut position. MACS2 were used for peak calling and HOMER for motif discovery. Differential binding analysis was carried out using DiffBind (R function).

\section{Cis-regulatory elements annotations}

Putative cis-regulatory elements (CRE) were annotated over the Schmidtea mediterranea genome version S2F2. For this purpose, both ChIP-seq and ATAC-seq data from all 
collected samples were used. Narrowpeaks over the genome were identified using MACS2 (see ATAC-seq and ChIPmentation analysis section of materials and methods). These peaks were merged using the mergePeaks command of the HOMER software suit. Finally, regions over the genome were classified as either putative promoters, or putative enhancers, according to their evidences regarding ATAC-seq and ChIP-seq peak coverage. Only those regions called as peaks on at least two samples were considered, and the rest were discarded for the CRE annotation.

Peak regions with only ATAC-seq evidences were classified as core promoters $(<100 \mathrm{bp}$ upstream of an annotated TSS) or proximal promoters (between 500 and 100 bp upstream of a TSS). Finally, peaks with CHIP-seq evidences were classified as either proximal enhancers (within 2000 bp of an annotated TSS) or distal enhancers (between 2000 and $10000 \mathrm{bp}$ of a TSS).

\section{Motif finding}

Putative transcription factor binding sites were identified and annotated on all these enhancer and promoter regions by using the HOMER's findMotifsGenome command, scanning these regions using the motifs provided by the software suite (known motifs).

Transcription factor motif overrepresentation analyses were also performed using the findMotifsGenome command of HOMER. Motifs were called as overrepresented using an adjusted p-value cutoff of 0.05 .

\section{Integration with online resources}

A new plugin for the PlanNET web service (88), called tf tools, was developed in order to integrate the putative $\mathrm{CRE}$ dataset with existing planarian resources. A search tool for exploring genes according to the presence or absence of transcription factor binding motifs was developed, and the putative CRE elements were incorporated to the existing gene cards in PlanNET and to our genome browser instance. The website, the source code of the 
plugin, and downloads for all the annotations, will be released upon publication on https://compgen.bio.ub.edu/PlanNET.

\section{RNA sequencing sample preparation and analysis}

RNA-sequencing samples were obtained after trough the soaking protocol. At the corresponding time point (0-24-48-72 hours of regeneration), animals were placed in a Petri dish with cold $1 \% \mathrm{HCl}$ (diluted in water) for 2' and then transferred to a new Petri dish with cold PBS 1X. Two washes were performed with cold PBS 1X and animals were transferred to cold RNAlater for 20' placed in ice. Afterwards, planarians were amputated in a Peltier Cell with a clean blade, to obtain the blastemas and post-blastemas. Fragments were washed with RNAlater (Invitrogen) and 50\% RNAlater /Trizol. Finally, liquids were removed and $100 \mu \mathrm{l}$ of Trlizol reagent (Invitrogen) was added. Total mRNA extraction was performed as described in (89). Three biological replicates were used per time point. Each biological replicate was composed by eight animal fragments. Libraries preparation and sequencing was carried out by Centre Nacional d'Anàlisi Genòmic (CNAG).

RNA reads were mapped against the planarian genome version S2F2 (39) using the STAR software tool (90). Lowly expressed genes were filtered by removing genes with less than 1 count-per-million (CPM). Two biological replicates were removed due to ineffective wnt1 inhibition. Differentially expressed genes were detected using the lima-voom pipeline (91), using an FDR cut-off of 0.05 and a log fold change cut-off of \pm 0.5 .

\section{Whole mount in situ hybridization (ISH)}

RNA probes were synthesized in vitro (Roche) using T7 or SP6 polymerases and DIG- or FITC- modified, purified with ethanol and 7.5M of ammonium acetate, diluted in $25 \mu \mathrm{ldd} \mathrm{H}_{2} \mathrm{O}$ and adjusted to a final concentration of $250 \mathrm{ng} / \mu \mathrm{I}$. For colorimetric ISH was performed (92): animals were killed in 5\% N-acetyl-L-cysteine (NAC), fixed in $4 \%$ formaldehyde (FA), permeabilized with Reduction solution for $5^{\prime}$ at $37^{\circ} \mathrm{C}$ and stored in methanol at $-20^{\circ} \mathrm{C}$. 
Following overnight hybridization, samples were washed twice with $2 x$ SSC with Triton-X (SSCTx), 0.2x SSCTx, 0.02x SSCTx and MABTween. Subsequently, blocking was in 5\% Horse Serum (X?) and 0.5\% Western Blocking Reagent (Roche) MABTween solution and anti-DIG-POD was used. Antibody was washed for 2 hours followed by NBT/BCIP development.

\section{Immunohistochemistry staining}

Whole mount immunohistochemistry was performed as (93): animals were killed with cold $2 \% \mathrm{HCl}$ and fixed with $4 \% \mathrm{FA}$ at RT. After 4 hours in blocking solution (1\% BSA in PBS Triton-X $0.3 \%$, animals were stained overnight at $4^{\circ} \mathrm{C}$. Animals were washed extensively with PBSTx, blocked for 2 hours and stained overnight at $4^{\circ} \mathrm{C}$. The following antibodies used in these experiments: mouse anti-synapsin (anti-SYNORF1, 1:50; Developmental Studies Hybridoma Bank) and anti-Smed-b-catenin2 (1:1000; (94)). The secondary antibodies used were Alexa 488-conjugated goat anti-mouse (1:400; Molecular Probes; A28175) and Alexa 568-conjugated goat anti- rabbit (1:1000; Molecular Probes; A-11011). Nuclei were stained with DAPI (1:5000).

\section{Image acquisition}

in vivo images were acquired with X. Brightfield colorimetric ISH images were obtained with a ProgRes C3 camera from Jenoptik (Jena, TH, Germany). A Zeiss LSM 880 confocal microscope (Zeiss, Oberkochen, Germany) was used to obtain confocal images of wholemount immunostainings. Fiji/lmageJ was used to show representative confocal stacks for each experimental condition are shown.

\section{Data availability}

Data set generated is deposit in GenBank with the accession numbers: XXX

\section{Acknowledgements}


We wish to thank all members of the Emili Saló, Teresa Adell and Francesc Cebrià labs for their suggestions and discussion of the results. A thought to the memory of José Luis Gomez Skarmeta, who passed away on September 16, 2020 while this manuscript was in progress; he was an exceptional promoter of scientific collaborations.

\section{Author Contributions}

E.P-C. and T.A. designed the study and wrote the manuscript; E.P-C., M.M-B and S.C-L. performed and analyzed genomic experiments; P.C-C performed foxG RNAi experiments; S.C-L. and M.M-B performed the bioinformatic research; J.F.A supervised the bioinformatic research. M.M-B, M.S.M., G.N.W. and J.L.G-S. performed the Chip-seq experiments and analyzed the results; E.S. and T.A. received the funding and supervised the research.

\section{Funding}

E.P-C. is the recipient of an FPI (Formación del Profesorado Investigador) scholarship from the Spanish Ministerio de Ciencia, Innovación y Universidades. M.M-B was supported by the People Programme (Marie Curie Actions) of the European Union's Seventh Framework Programme FP7 under REA grant agreement number 607142 (DevCom). M.M-B also thanks the John and Pamela Salter Trust for funding support. ES and TA received funding from the Ministerio de Educación y Ciencia (grant number BFU2017-83755-P and BFU201456055-P). E.S. and T.A. benefit from 2017SGR-1455 from AGAUR (Genereliat de Catalunya). ES received funding from AGAUR (Generalitat de Catalunya: grant number 2009SGR1018). JLG-S received funding from the ERC (Grant 944 Agreement No. 740041), the Spanish Ministerio de Economía y Competitividad (Grant No. 945 BFU2016-74961-P) and the institutional grant Unidad de Excelencia María de Maeztu (MDM946 2016-0687). The funder had no role in the study design, data collection and analysis, decision to publish, or manuscript preparation.

\section{Declaration of Interests}


The authors declare no conflict of interest. The funders had no role in the design of the study; in the collection, analyses, or interpretation of data; in the writing of the manuscript, or in the decision to publish the results.

\section{References}

1. Anderson C, Stern CD. Organizers in Development. In: Current Topics in

Developmental Biology [Internet]. 2016 [cited 2019 Sep 8]. p. 435-54. Available from: http://www.ncbi.nlm.nih.gov/pubmed/26969994

2. Martinez Arias A, Steventon B. On the nature and function of organizers. Dev [Internet]. 2018 [cited 2019 Mar 28];145(5). Available from:

http://dev.biologists.org/content/develop/145/5/dev159525.full.pdf

3. Stern CD. Initial patterning of the central nervous system: How many organizers? Nat Rev Neurosci [Internet]. 2001 Feb 1;2(2):92-8. Available from: http://www.nature.com/articles/35053563

4. Anderson $\mathrm{C}$, Khan MAF, Wong F, Solovieva T, Oliveira NMM, Baldock RA, et al. A strategy to discover new organizers identifies a putative heart organizer. Nat Commun [Internet]. 2016;7(May):12656. Available from:

http://www.nature.com/doifinder/10.1038/ncomms12656

5. De Robertis EM, Larraín J, Oelgeschläger M, Wessely O. The establishment of Spemann's organizer and patterning of the vertebrate embryo. Nat Rev Genet. 2000;1(3):171-81.

6. De Robertis EM. Spemann's organizer and self-regulation in amphibian embryos. Nat Rev Mol Cell Biol [Internet]. 2006 Apr 1 [cited 2020 Dec 2];7(4):296-302. Available from: http://www.xenbase.org/

7. Thisse B, Thisse C. Formation of the vertebrate embryo: Moving beyond the Spemann organizer [Internet]. Vol. 42, Seminars in Cell and Developmental Biology. 
2015 [cited 2019 Sep 3]. p. 94-102. Available from:

http://dx.doi.org/10.1016/j.semcdb.2015.05.007

8. Spemann $\mathrm{H}$, Mangold $\mathrm{H}$. über Induktion von Embryonalanlagen durch Implantation artfremder Organisatoren. Arch für Mikroskopische Anat und Entwicklungsmechanik [Internet]. 1924 Sep [cited 2019 Aug 28];100(3-4):599-638. Available from: http://link.springer.com/10.1007/BF02108133

9. Bachvarova RF, Skromne I, Stern CD. Induction of primitive streak and Hensen's node by the posterior marginal zone in the early chick embryo. Development [Internet]. 1998 Sep;125(17):3521-34. Available from: http://www.ncbi.nlm.nih.gov/pubmed/9693154

10. Shih J, Fraser SE. Characterizing the zebrafish organizer: Microsurgical analysis at the early-shield stage. Development. 1996;122(4):1313-22.

11. Zuniga A. Next generation limb development and evolution: old questions, new perspectives. Development [Internet]. 2015 Nov 15;142(22):3810-20. Available from: http://dev.biologists.org/lookup/doi/10.1242/dev.125757

12. McQueen C, Towers M. Establishing the pattern of the vertebrate limb. Development [Internet]. 2020 Sep 1 [cited 2020 Nov 21];147(17):dev177956. Available from: https://dev.biologists.org/content/147/17/dev177956

13. Browne EN. The production of new hydranths in Hydra by the insertion of small grafts. J Exp Zool [Internet]. 1909 Aug 1 [cited 2019 Aug 28];7(1):1-23. Available from: http://doi.wiley.com/10.1002/jez.1400070102

14. Wagner DE, Wang IE, Reddien PW. Clonogenic neoblasts are pluripotent adult stem cells that underlie planarian regeneration. Science [Internet]. 2011 May 13 [cited 2014 Jan 23];332(6031):811-6. Available from:

http://www.pubmedcentral.nih.gov/articlerender.fcgi?artid=3338249\&tool=pmcentrez\& 
rendertype $=$ abstract

15. Baguna J, Salo E, Auladell C. Regeneration and pattern formation in planarians. III. Evidence that neoblasts are totipotent stem cells and the source of blastema cells. Development. 1989;107(1):77-86.

16. Witchley JN, Mayer M, Wagner DE, Owen JH, Reddien PW. Muscle cells provide instructions for planarian regeneration. Cell Rep [Internet]. 2013 Aug 29 [cited 2014 Feb 26];4(4):633-41. Available from: http://www.ncbi.nlm.nih.gov/pubmed/23954785

17. Scimone ML, Cote LE, Rogers T, Reddien PW. Two FGFRL-Wnt circuits organize the planarian anteroposterior axis. Elife [Internet]. 2016 Apr 11 [cited 2016 Apr 13];5. Available from: http://www.ncbi.nlm.nih.gov/pubmed/27063937

18. Lander R, Petersen CP. Wnt, Ptk7, and FGFRL expression gradients control trunk positional identity in planarian regeneration. Elife [Internet]. 2016 Apr 13;5. Available from: https://elifesciences.org/articles/12850

19. Scimone ML, Cote LE, Reddien PW. Orthogonal muscle fibres have different instructive roles in planarian regeneration. Nature [Internet]. 2017 Nov 22;551(7682):623-8. Available from:

http://www.nature.com/doifinder/10.1038/nature24660

20. Petersen CP, Reddien PW. Polarized notum activation at wounds inhibits Wnt function to promote planarian head regeneration. Science. $2011 ; 332(6031): 852-5$.

21. Adell T, Salò E, Boutos M, Bartscherer K. Smed-Evi/Wntless is required for $\beta$-catenindependent and -independent processes during planarian regeneration. Development. 2009;136(6):905-10.

22. Petersen CP, Reddien PW. A wound-induced Wnt expression program controls planarian regeneration polarity. Proc Natl Acad Sci U S A. 2009;106(40):17061-6.

23. Petersen CP, Reddien PW. Smed-betacatenin-1 is required for anteroposterior 
blastema polarity in planarian regeneration. Science. 2008;319(5861):327-30.

24. Iglesias M, Gomez-Skarmeta JL, Saló E, Adell T. Silencing of Smed-betacatenin1 generates radial-like hypercephalized planarians. Development [Internet]. $2008 \mathrm{Apr}$ [cited 2014 Mar 27];135(7):1215-21. Available from:

http://www.ncbi.nlm.nih.gov/pubmed/18287199

25. Sureda-Gómez M, Martín-Durán JM, Adell T. Localization of planarian BCATENIN-1 reveals multiple roles during anterior-posterior regeneration and organogenesis.

Development [Internet]. 2016;(October):dev.135152. Available from:

http://dev.biologists.org/lookup/doi/10.1242/dev.135152

26. Stückemann T, Cleland JP, Werner S, Vu HT-K, Liu SY, Friedrich BM, et al.

Antagonistic self-organizing patterning systems control maintenance and regeneration of the anteroposterior axis in planarians. Dev Cell. 2017;in press:248-63.

27. Tewari AG, Stern SR, Oderberg IM, Reddien PW. Cellular and Molecular Responses Unique to Major Injury Are Dispensable for Planarian Regeneration. Cell Rep [Internet]. 2018;25(9):2577-2590.e3. Available from:

https://doi.org/10.1016/j.celrep.2018.11.004

28. Gurley KA, Rink JC, Sánchez Alvarado A. $\beta$-Catenin Defines Head Versus Tail Identity During Planarian Regeneration and Homeostasis. Science (80- ). 2008;319(5861):323-7.

29. Gurley K a., Elliott S a., Simakov O, Schmidt H a., Holstein TW, Alvarado AS. Expression of secreted Wnt pathway components reveals unexpected complexity of the planarian amputation response. Dev Biol. 2010;347(1):24-39.

30. Vásquez-Doorman C, Petersen CP. zic-1 Expression in Planarian Neoblasts after Injury Controls Anterior Pole Regeneration. PLoS Genet. 2014;10(7).

31. Scimone ML, Lapan SW, Reddien PW. A forkhead transcription factor is wound- 
induced at the planarian midline and required for anterior pole regeneration. PLoS Genet [Internet]. 2014 Jan [cited 2014 Aug 27];10(1):e1003999. Available from: http://www.pubmedcentral.nih.gov/articlerender.fcgi?artid=3886891\&tool=pmcentrez\& rendertype $=$ abstract

32. Vogg MC, Owlarn S, Pérez Rico Y a, Xie J, Suzuki Y, Gentile L, et al. Stem celldependent formation of a functional anterior regeneration pole in planarians requires Zic and Forkhead transcription factors. Dev Biol [Internet]. 2014 Jun 15 [cited 2014 Oct 2];390(2):136-48. Available from: http://www.ncbi.nlm.nih.gov/pubmed/24704339

33. Chen C-CG, Wang IE, Reddien PW. pbx is required for pole and eye regeneration in planarians. Development [Internet]. 2013 Feb 15 [cited 2014 Jan 23];140(4):719-29. Available from: http://dev.biologists.org/content/140/4/719.long

34. Blassberg RA, Felix DA, Tejada-Romero B, Aboobaker AA. PBX/extradenticle is required to re-establish axial structures and polarity during planarian regeneration. Development [Internet]. 2013 Feb 15 [cited 2014 Jan 23];140(4):730-9. Available from: http://dev.biologists.org/content/140/4/730.long

35. Hayashi T, Motoishi M, Yazawa S, Itomi K, Tanegashima C, Nishimura O, et al. A LIM-homeobox gene is required for differentiation of Wnt-expressing cells at the posterior end of the planarian body. Development [Internet]. 2011;138(17):3679-88. Available from: http://dev.biologists.org/cgi/doi/10.1242/dev.060194

36. März M, Seebeck F, Bartscherer K. A Pitx transcription factor controls the establishment and maintenance of the serotonergic lineage in planarians. Development [Internet]. 2013 Nov [cited 2014 Feb 28];140(22):4499-509. Available from: http://www.ncbi.nlm.nih.gov/pubmed/24131630

37. Reuter H, März M, Vogg MC, Eccles D, Grífol-Boldú L, Wehner D, et al. $\beta$-CateninDependent Control of Positional Information along the AP Body Axis in Planarians Involves a Teashirt Family Member. Cell Rep [Internet]. 2014 Dec 30 [cited 2015 Jan 
9];1-13. Available from: http://www.ncbi.nlm.nih.gov/pubmed/25558068

38. Owen JH, Wagner DE, Chen C-C, Petersen CP, Reddien PW. Teashirt Is Required for Head-Versus-Tail Regeneration Polarity in Planarians. Development [Internet]. 2015;(February):1-11. Available from:

http://dev.biologists.org/cgi/doi/10.1242/dev.119685

39. Grohme MA, Schloissnig S, Rozanski A, Pippel M, Young G, Winkler S, et al. The genome of Schmidtea mediterranea highlights the plasticity of cellular core mechanisms. Nat Publ Gr [Internet]. 2018;1-24. Available from: http://dx.doi.org/10.1038/nature25473

40. Calo E, Wysocka J. Modification of Enhancer Chromatin: What, How, and Why? Mol Cell [Internet]. 2013;49(5):825-37. Available from: http://dx.doi.org/10.1016/j.molcel.2013.01.038

41. Shlyueva D, Stampfel G, Stark A. Transcriptional enhancers: from properties to genome-wide predictions. Nat Rev Genet [Internet]. 2014;15(4):272-86. Available from: http://www.nature.com/doifinder/10.1038/nrg3682

42. Hill EM, Petersen CP. Wnt/Notum spatial feedback inhibition controls neoblast differentiation to regulate reversible growth of the planarian brain. Development [Internet]. 2015;142(24):4217-29. Available from:

http://dev.biologists.org/cgi/doi/10.1242/dev.123612

43. Sureda-Gómez M, Pascual-Carreras E, Adell T. Posterior Wnts Have Distinct Roles in Specification and Patterning of the Planarian Posterior Region. Int J Mol Sci [Internet]. 2015 Nov 5;16(11):26543-54. Available from: http://www.mdpi.com/1422$0067 / 16 / 11 / 25970 /$

44. Wurtzel O, Cote LE, Poirier A, Satija R, Regev A, Reddien PW. A Generic and CellType-Specific Wound Response Precedes Regeneration in Planarians. Dev Cell 
[Internet]. 2015 Dec;35(5):632-45. Available from:

http://linkinghub.elsevier.com/retrieve/pii/S1534580715007182

45. Scimone ML, Cote LE, Rogers T, Reddien PW. Two FGFRL-Wnt circuits organize the planarian anteroposterior axis. Intergovernmental Panel on Climate Change, editor. Elife [Internet]. 2016 Apr 11;5:1-30. Available from: https://www.cambridge.org/core/product/identifier/CBO9781107415324A009/type/boo k_part

46. Tewari AG, Owen JH, Petersen CP, Wagner DE, Reddien PW. A small set of conserved genes, including sp5 and Hox, are activated by Wnt signaling in the posterior of planarians and acoels [Internet]. Vol. 15, PLoS genetics. 2019. e1008401 p. Available from: http://dx.doi.org/10.1371/journal.pgen.1008401

47. Ramakrishnan A-B, Cadigan KM. Wnt target genes and where to find them. F1000Research [Internet]. 2017 May 24;6(May):746. Available from: https://f1000research.com/articles/6-746/v1

48. Alkhatib SG, Landry JW. The Nucleosome Remodeling Factor. FEBS Lett [Internet]. 2011 Oct 20 [cited 2020 Dec 2];585(20):3197-207. Available from: /pmc/articles/PMC4839296/?report=abstract

49. Boudreault AA, Cronier D, Selleck W, Lacoste N, Utley RT, Allard S, et al. Yeast enhancer of polycomb defines global Esa1-dependent acetylation of chromatin. Genes Dev [Internet]. 2003 Jun 1 [cited 2020 Dec 2];17(11):1415-28. Available from: /pmc/articles/PMC196073/?report=abstract

50. Gasperini M, Tome JM, Shendure J. Towards a comprehensive catalogue of validated and target-linked human enhancers. Nat Rev Genet [Internet]. 2020 May 27;21(5):292-310. Available from: http://feeds.nature.com/ r/nrg/rss/current/ 3/fevZFDz5GNk/s41576-019-02090?utm_source=researcher_app\&utm_medium=referral\&utm_campaign=RESR_MRKT 
_Researcher_inbound

51. Li DJ, McMann CL, Reddien PW. Nuclear receptor NR4A is required for patterning at the ends of the planarian anterior-posterior axis. Elife. 2019;8.

52. Castillo-Lara S, Pascual-Carreras E, Abril JF. PlanExp: intuitive integration of complex RNA-seq datasets with planarian omics resources. Bioinformatics. 2020;36(6):1889_ 95.

53. Noyes MB, Meng X, Wakabayashi A, Sinha S, Brodsky MH, Wolfe SA. A systematic characterization of factors that regulate Drosophila segmentation via a bacterial onehybrid system. Nucleic Acids Res. 2008;36(8):2547-60.

54. Junion G, Spivakov M, Girardot C, Braun M, Gustafson EH, Birney E, et al. A Transcription Factor Collective Defines Cardiac Cell Fate and Reflects Lineage History. Cell [Internet]. 2012 Feb;148(3):473-86. Available from: http://dx.doi.org/10.1016/j.cell.2012.01.030

55. Aztekin C, Hiscock TW, Marioni JC, Gurdon JB, Simons BD, Jullien J. Identification of a regeneration-organizing cell in the Xenopus tail. Science (80- ) [Internet]. 2019;364(6441):653-8. Available from:

http://www.sciencemag.org/lookup/doi/10.1126/science.aav9996

56. Wehner D, Cizelsky W, Vasudevaro MD, Özhan G, Haase C, Kagermeier-Schenk B, et al. Wnt/ $\beta$-catenin signaling defines organizing centers that orchestrate growth and differentiation of the regenerating zebrafish caudal fin. Cell Rep. 2014;6(3):467-81.

57. Lengfeld T, Watanabe H, Simakov O, Lindgens D, Gee L, Law L, et al. Multiple Wnts are involved in Hydra organizer formation and regeneration. Dev Biol [Internet]. 2009 Jun 1 [cited 2014 Nov 26];330(1):186-99. Available from: http://www.ncbi.nlm.nih.gov/pubmed/19217898

58. Vogg MC, Beccari L, Iglesias Ollé L, Rampon C, Vriz S, Perruchoud C, et al. An 
evolutionarily-conserved Wnt3/ß-catenin/Sp5 feedback loop restricts head organizer activity in Hydra. Nat Commun [Internet]. 2019 [cited 2019 Jan 29];10(1). Available from: https://doi.org/10.1038/s41467-018-08242-2

59. Cao R, Wang L, Wang H, Xia L, Erdjument-Bromage H, Tempst $\mathrm{P}$, et al. Role of Histone H3 Lysine 27 Methylation in Polycomb-Group Silencing. Science (80- ) [Internet]. 2002 Nov 1;298(5595):1039-43. Available from: https://www.sciencemag.org/lookup/doi/10.1126/science.1076997

60. Mosimann C, Hausmann G, Basler K. $\beta$-Catenin hits chromatin : regulation of Wnt target gene activation. 2009;10(April).

61. Currie KW, Pearson BJ. Transcription factors $\operatorname{lh} \times 1 / 5-1$ and pitx are required for the maintenance and regeneration of serotonergic neurons in planarians. Development [Internet]. 2013 Sep [cited 2014 Aug 4];140(17):3577-88. Available from: http://www.ncbi.nlm.nih.gov/pubmed/23903188

62. Anastasiadi D, Esteve-Codina A, Piferrer F. Consistent inverse correlation between DNA methylation of the first intron and gene expression across tissues and species. Epigenetics and Chromatin [Internet]. 2018;11(1):1-17. Available from: https://doi.org/10.1186/s13072-018-0205-1

63. Marais G, Nouvellet P, Keightley PD, Charlesworth B. Intron size and exon evolution in Drosophila. Genetics [Internet]. 2005 May [cited 2020 Apr 22];170(1):481-5. Available from: http://www.ncbi.nlm.nih.gov/pubmed/15781704

64. Haddrill PR, Charlesworth B, Halligan DL, Andolfatto P. Patterns of intron sequence evolution in Drosophila are dependent upon length and GC content. Genome Biol [Internet]. 2005 [cited 2020 Apr 22];6(8):R67. Available from: http://www.ncbi.nlm.nih.gov/pubmed/16086849

65. Carullo NVN, Simon RC, Salisbury AJ, Revanna JS, Bunner KD, Savell KE, et al. 
Enhancer RNAs are necessary and sufficient for activity-dependent neuronal gene transcription. bioRxiv [Internet]. 2018;270967. Available from:

http://dx.doi.org/10.1101/270967\%0Ahttps://www.biorxiv.org/content/10.1101/270967 v2.abstract\%0Ahttp://dx.doi.org/10.1101/270967\%0Ahttps://www.biorxiv.org/content/1 0.1101/270967v2.abstract

66. Guigó R, Corominas M, Mishra RK, Serras F, Vizcaya-Molina E, Klein CC. Damageresponsive elements in Drosophila regeneration . Genome Res. 2018;28(12):185266.

67. Ramirez AN, Loubet-senear K, Srivastava M, Ramirez AN, Loubet-senear K, Srivastava M. A Regulatory Program for Initiation of Wnt Signaling during Posterior Regeneration II II A Regulatory Program for Initiation of Wnt Signaling during Posterior Regeneration. CellReports [Internet]. 2020;32(9):108098. Available from: https://doi.org/10.1016/j.celrep.2020.108098

68. Harris RE, Setiawan L, Saul J, Hariharan IK. Localized epigenetic silencing of a damage-activated WNT enhancer limits regeneration in mature Drosophila imaginal discs. Elife. 2016;5(FEBRUARY2016):1-28.

69. Reddy PC, Gungi A, Ubhe S, Galande S. Epigenomic landscape of enhancer elements during Hydra head organizer formation. Epigenetics Chromatin [Internet]. 2020 Dec 12 [cited 2020 Oct 14];13(1):43. Available from: https://epigeneticsandchromatin.biomedcentral.com/articles/10.1186/s13072-02000364-6

70. Murad R, Macias-Munoz A, Wong A, Ma X, Mortazavi A. Integrative analysis of Hydra head regeneration reveals activation of distal enhancer-like elements. bioRxiv [Internet]. 2019;544049. Available from: https://www.biorxiv.org/content/10.1101/544049v1.abstract

71. Gehrke AR, Neverett E, Luo YJ, Brandt A, Ricci L, Hulett RE, et al. Acoel genome 
reveals the regulatory landscape of whole-body regeneration. Science (80- )

[Internet]. 2019 [cited 2019 Mar 14];363(6432). Available from:

http://science.sciencemag.org/

72. Wong ES, Zheng D, Tan SZ, Bower NL, Garside V, Vanwalleghem G, et al. Deep conservation of the enhancer regulatory code in animals. Science (80- ) [Internet]. 2020 Nov 6 [cited 2020 Nov 6];370(6517). Available from:

https://doi.org/10.1126/science.aax8137

73. Yazawa S, Umesono Y, Hayashi T, Tarui H, Agata K. Planarian hedgehog/patched establishes anterior-posterior polarity by regulating Wnt signaling. Proc Natl Acad Sci U S A [Internet]. 2009 [cited 2019 Apr 30];106(52):22329-34. Available from: https://www-pnas-org.sire.ub.edu/content/pnas/106/52/22329.full.pdf

74. Rink JC, Gurley KA, Elliott SA, Sanchez Alvarado A. Planarian Hh Signaling Regulates Regeneration Polarity and Links Hh Pathway Evolution to Cilia. Science (80- ) [Internet]. 2009 Dec 4;326(5958):1406-10. Available from: https://www.sciencemag.org/lookup/doi/10.1126/science.1178712

75. Danesin C, Peres JN, Johansson M, Snowden V, Cording A, Papalopulu N, et al. Integration of Telencephalic Wnt and Hedgehog Signaling Center Activities by Foxg1. Dev Cell [Internet]. 2009 Apr 21 [cited 2020 Oct 15];16(4):576-87. Available from: http://www.cell.com/article/S1534580709000975/fulltext

76. Dong F, Liu D, Jiang F, Liu Y, Wu X, Qu X, et al. Conditional Deletion of Foxg1 Alleviates Demyelination and Facilitates Remyelination via the Wnt Signaling Pathway in Cuprizone-Induced Demyelinated Mice. Neurosci Bull [Internet]. 2020 Oct 5 [cited 2020 Oct 6]; Available from: http://link.springer.com/10.1007/s12264-020-00583-7

77. Kang J, Hu J, Karra R, Dickson AL, Tornini VA, Nachtrab G, et al. Modulation of tissue repair by regeneration enhancer elements. Nature [Internet]. 2016 Apr 6 [cited 2019 Sep 8];532(7598):201-6. Available from: 
http://www.nature.com/articles/nature17644

78. Thompson JD, Ou J, Lee N, Shin K, Cigliola V, Song L, et al. Identification and requirements of enhancers that direct gene expression during zebrafish fin regeneration. Development [Internet]. 2020 Jul 15;147(14):dev191262. Available from: http://dev.biologists.org/lookup/doi/10.1242/dev.191262

79. Lee HJ, Hou Y, Chen Y, Dailey ZZ, Riddihough A, Jang HS, et al. Regenerating zebrafish fin epigenome is characterized by stable lineage-specific DNA methylation and dynamic chromatin accessibility. Genome Biol. 2020;21(1):1-17.

80. Wang W, Hu C-K, Zeng A, Alegre D, Hu D, Gotting K, et al. Changes in regenerationresponsive enhancers shape regenerative capacities in vertebrates. [cited 2020 Sep 4]; Available from: https://doi.org/10.1126/science.aaz3090

81. Liu SY, Selck C, Friedrich B, Lutz R, Vila-Farré M, Dahl A, et al. Reactivating head regrowth in a regeneration-deficient planarian species. Nature. 2013;500(7460):81-4.

82. Sousa N, Adell T. Maintenance of Schmidtea mediterranea in the Laboratory. BIOPROTOCOL [Internet]. 2018 [cited 2020 Nov 22];8(19). Available from: https://bioprotocol.org/e3040

83. Fernandéz-Taboada E, Moritz S, Zeuschner D, Stehling M, Schöler HR, Saló E, et al. Smed-SmB, a member of the LSm protein superfamily, is essential for chromatoid body organization and planarian stem cell proliferation. Development [Internet]. 2010 Apr 1 [cited 2014 Aug 27];137(7):1055-65. Available from: http://dev.biologists.org/content/137/7/1055.long

84. Buenrostro JD, Wu B, Chang HY, Greenleaf WJ. ATAC-seq: A method for assaying chromatin accessibility genome-wide. Curr Protoc Mol Biol [Internet]. 2015 Jan 5 [cited 2019 Sep 17];2015:21.29.1-21.29.9. Available from: http://www.ncbi.nlm.nih.gov/pubmed/25559105 
85. Lukoseviciute M, Gavriouchkina D, Williams RM, Hochgreb-Hagele T, Senanayake U, Chong-Morrison V, et al. From Pioneer to Repressor: Bimodal foxd3 Activity Dynamically Remodels Neural Crest Regulatory Landscape In Vivo. Dev Cell [Internet]. 2018 Dec 3 [cited 2019 Sep 17];47(5):608-628.e6. Available from: http://www.ncbi.nlm.nih.gov/pubmed/30513303

86. Schmidl C, Rendeiro AF, Sheffield NC, Bock C. ChIPmentation: Fast, robust, lowinput ChIP-seq for histones and transcription factors. Nat Methods [Internet]. 2015 Oct 17 [cited 2019 Sep 17];12(10):963-5. Available from: http://www.nature.com/articles/nmeth.3542

87. Buenrostro JD, Giresi PG, Zaba LC, Chang HY, Greenleaf WJ. Transposition of native chromatin for fast and sensitive epigenomic profiling of open chromatin, DNAbinding proteins and nucleosome position. Nat Methods [Internet]. 2013 Dec 6 [cited 2019 Sep 17];10(12):1213-8. Available from:

http://www.ncbi.nlm.nih.gov/pubmed/24097267

88. Castillo-Lara S, Abril JF. PlanNET: Homology-based predicted interactome for multiple planarian transcriptomes. Kelso J, editor. Bioinformatics [Internet]. $2018 \mathrm{Mar}$ 15 [cited 2020 Nov 6];34(6):1016-23. Available from: https://academic.oup.com/bioinformatics/article/34/6/1016/4657068

89. Almuedo-Castillo M, Crespo X, Seebeck F, Bartscherer K, Salò E, Adell T. JNK controls the onset of mitosis in planarian stem cells and triggers apoptotic cell death required for regeneration and remodeling. PLoS Genet [Internet]. 2014 Jun [cited 2014 Aug 6];10(6):e1004400. Available from:

http://www.pubmedcentral.nih.gov/articlerender.fcgi?artid=4055413\&tool=pmcentrez\& rendertype=abstract

90. Dobin A, Davis CA, Schlesinger F, Drenkow J, Zaleski C, Jha S, et al. STAR: Ultrafast universal RNA-seq aligner. Bioinformatics [Internet]. 2013 Jan 1 [cited 2019 Sep 
2];29(1):15-21. Available from: http://www.ncbi.nlm.nih.gov/pubmed/23104886

91. Ritchie ME, Phipson B, Wu D, Hu Y, Law CW, Shi W, et al. Limma powers differential expression analyses for RNA-sequencing and microarray studies. Nucleic Acids Res [Internet]. 2015 Apr 20 [cited 2019 Sep 2];43(7):e47. Available from:

http://academic.oup.com/nar/article/43/7/e47/2414268/limma-powers-differentialexpression-analyses-for

92. Currie KW, Brown DDR, Zhu S, Xu CJ, Voisin V, Bader GD, et al. HOX gene complement and expression in the planarian Schmidtea mediterranea. Evodevo [Internet]. 2016 [cited 2019 Aug 19];7(1):7. Available from: www.geneious.

93. Ross KG, Omuro KC, Taylor MR, Munday RK, Hubert A, King RS, et al. Novel monoclonal antibodies to study tissue regeneration in planarians. BMC Dev Biol [Internet]. 2015 Jan [cited 2015 Sep 11];15:2. Available from:

http://www.pubmedcentral.nih.gov/articlerender.fcgi?artid=4307677\&tool=pmcentrez\& rendertype $=$ abstract

94. Chai G, Ma C, Bao K, Zheng L, Wang X, Sun Z, et al. Complete functional segregation of planarian beta-catenin-1 and -2 in mediating Wnt signaling and cell adhesion. J Biol Chem [Internet]. 2010 Jul 30 [cited 2015 Sep 13];285(31):24120-30. Available from:

http://www.pubmedcentral.nih.gov/articlerender.fcgi?artid=2911336\&tool=pmcentrez\& rendertype $=$ abstract

95. Fincher CT, Wurtzel O, de Hoog T, Kravarik KM, Reddien PW. Cell type transcriptome atlas for the planarian Schmidtea mediterranea. Science (80- ) [Internet]. 2018;1736(April):eaaq1736. Available from:

http://www.sciencemag.org/lookup/doi/10.1126/science.aaq1736

96. Rozanski A, Moon H, Brandl H, Martín-DuránDur JM, Grohme MA, Bartscherer K, et al. PlanMine 3.0-improvements to a mineable resource of flatworm biology and 
bioRxiv preprint doi: https://doi.org/10.1101/2020.12.08.416008; this version posted December 9, 2020. The copyright holder for this preprint (which was not certified by peer review) is the author/funder, who has granted bioRxiv a license to display the preprint in perpetuity. It is made available under aCC-BY-NC-ND 4.0 International license.

biodiversity. Nucleic Acids Res. 2019;47. 


\section{Supplementary information}

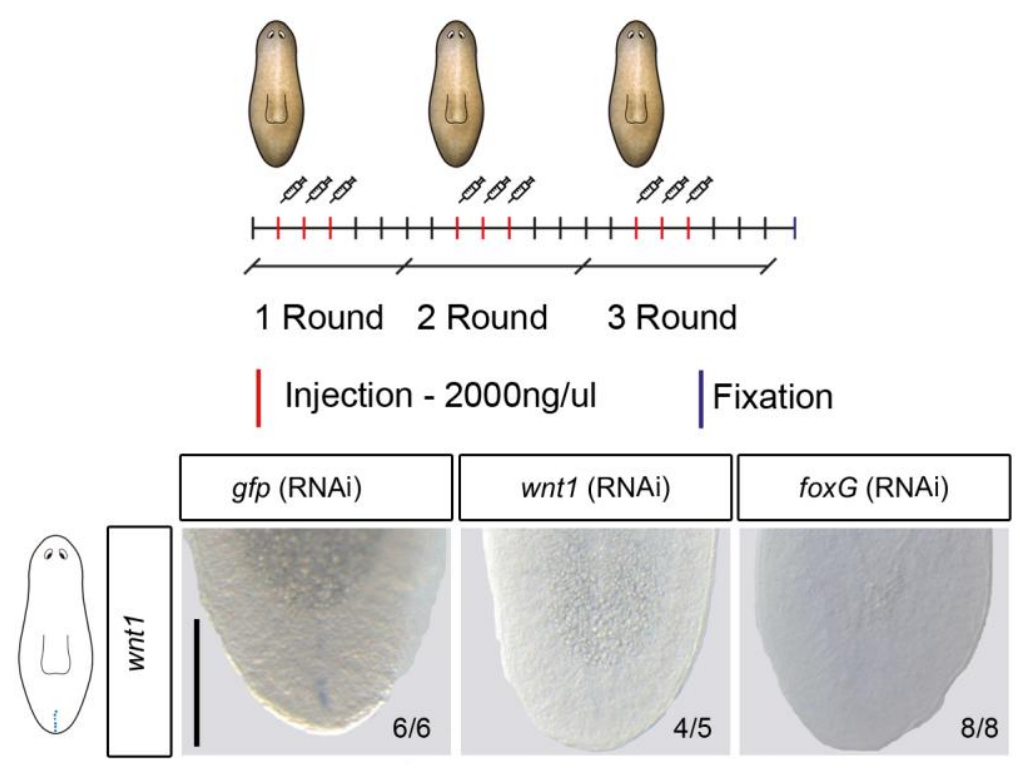

Figure S1. b WISH of wnt1 in intact animals after wnt1 and foxG inhibition reveal its absence. Schematic RNAi design illustration was added. 


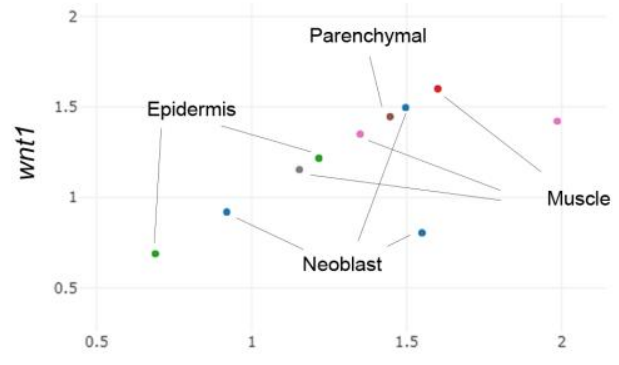

b

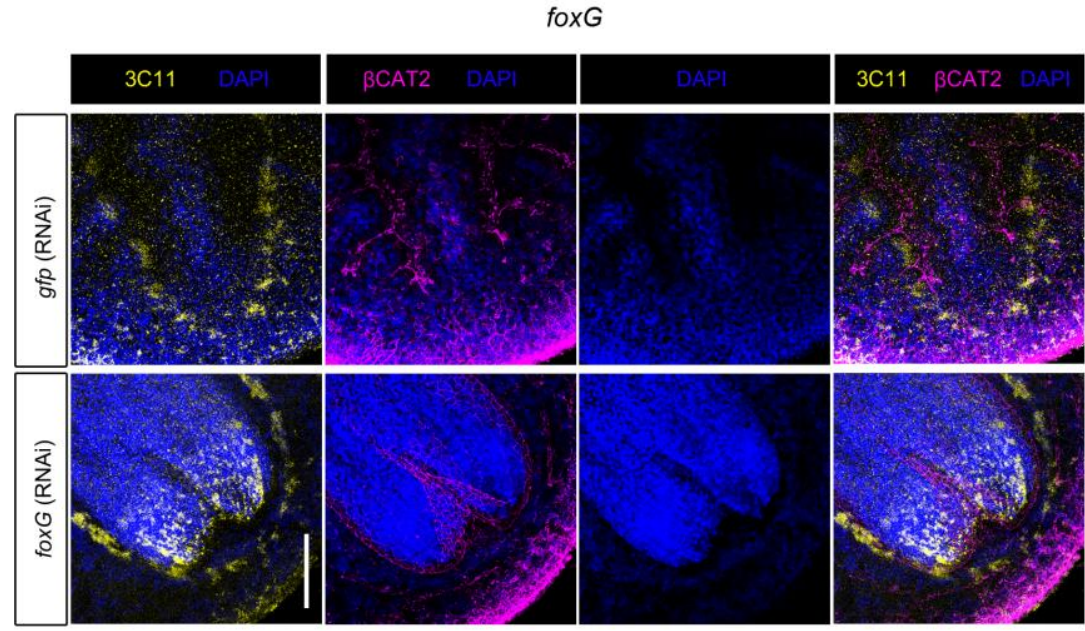

c

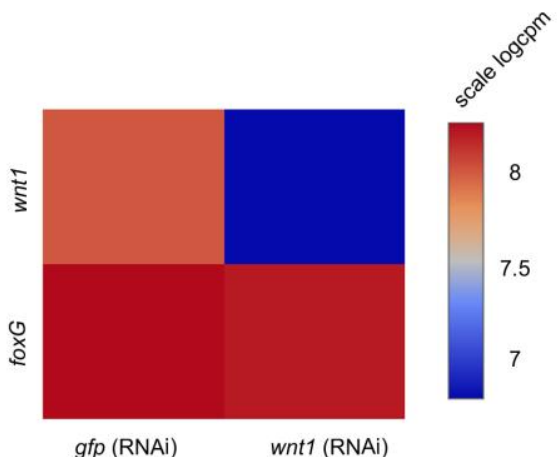

Figure S2. foxG (RNAi) animals showed lack of posterior regeneration. a SC-seq data from (95) demonstrates co-expression of wnt1 and foxG mainly in muscular and neuronal cells. b Tailless phenotype in foxG (RNAi) animals. c Heat map expression of foxG and wnt1 in wnt1 (RNAi) RNA-seq reveal that foxG is no down-regulated. Scale bar: $250 \mu \mathrm{m}$ in a, 100 $\mu \mathrm{m}$ in $\mathrm{b}$ and $\mathrm{c}$. 


\section{Table S1.}

Specific accessible chromatin regions (ACR) of anterior and posterior wounds at $12 \mathrm{hR}$. For each ACR, it is shown the scaffold location, its position within, the fold change respect the opposite tissue and the FDR statistic value. We also show the specific enhancers of anterior and posterior wounds at $12 \mathrm{hR}$. For each specific anterior and posterior enhancer, it is shown the scaffold location, its position within and how it behaves in notum or wnt1 (RNAi) conditions; being: accessible, slightly accessible, less accessible or non-accessible.

\section{Table S2.}

Results of the wnt1 (RNAi) RNA-seq experiment. Dif Expressed is shown all the genes upand down-regulated in the different regenerative time points. Down-regulated is shown just the genes down-regulated in the different regenerative time points including the presence of TCF motifs in the CREs (promoters and enhancers) and their presence in the dataset (46). Per genes is shown logFC, adj. P value, genome ID (39), condition (regenerative time point), gene name, Transcriptome ID (96) and its human homolog.

\section{Table S3.}

wnt1 (RNAi) RNA-seq down-regulated genes with a TCF binding site in its promoter or enhancer region.

\section{Table S4.}

Presence of accessible chromatin regions (ACRs) with ATAC or DNasa evidences, and active enhancers with ChIP evidences in the first intron of wnt1 gene in different species. indicated no evidences. The genome source per each species was added.

\section{Supplemental Data 1}

Genomic sequence of Smed-wnt1 locus showing the genomic organization of the gene (exons in green), the enhancers in the first intron (in yellow) and the FoxG binding motives (grey). 